\title{
Future Arrangements for Funding Higher Education
}

\section{IFS Commentary C115}

Lorraine Dearden

Alissa Goodman

Greg Kaplan

Gill Wyness

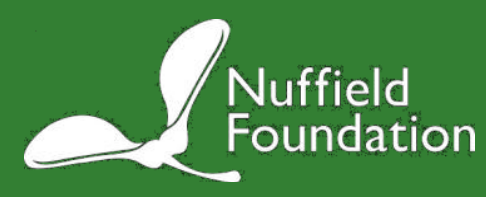




\title{
Future arrangements for funding higher education
}

\author{
Lorraine Dearden \\ Institute of Education, University of London \\ and Institute for Fiscal Studies \\ Alissa Goodman \\ Institute for Fiscal Studies \\ Greg Kaplan \\ University of Pennsylvania and Institute for Fiscal Studies \\ Gill Wyness \\ Institute for Fiscal Studies
}

APRIL 2010

Copyedited by Judith Payne

\section{Acknowledgements}

We gratefully acknowledge funding for this research from the Nuffield Foundation and from Universities UK. We would also like to thank members of our steering group for this project - in particular, Nicholas Barr, Juliet Chester, Paul Clark, Josh Hillman, Anton Muscatelli, and Neil Shephard - for helpful comments and suggestions. Despite all their help and suggestions, the usual disclaimer applies. The Nuffield Foundation has funded this project, but the views expressed are those of the authors and not necessarily those of the Foundation.
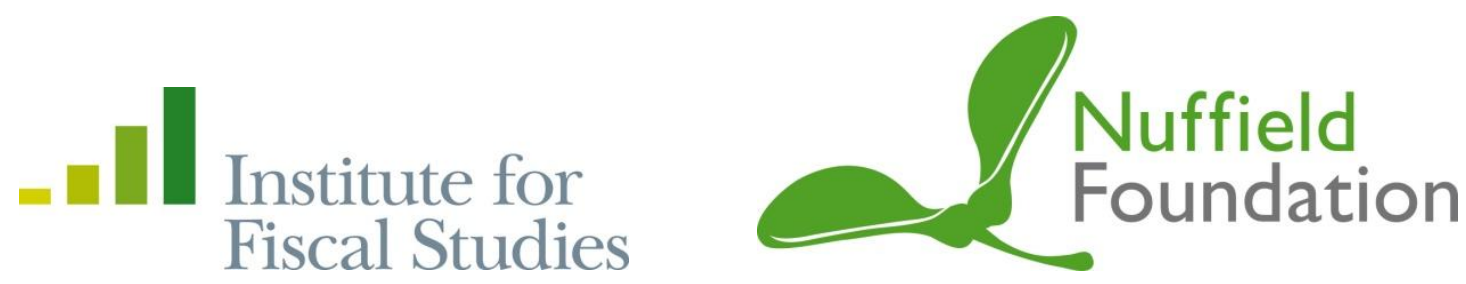


\section{Preface}

The results in this report are based on simulations of the lifetime earnings profiles of a particular sample of the population as follows:

- graduates of first full-time three-year degrees (therefore excluding foundation degrees).

In addition, we focus on a single cohort of graduates as follows:

- year of entry 2011;

- year of graduation 2014;

- graduation at age 22 .

As a result, these results cannot be generalised to the entire student/graduate population, and are not directly comparable to official government estimates of the cost of the current student support system. Government estimates of the cost of the current system are based on a much more heterogeneous sample of student/graduate types:

- undergraduates on all types of courses (degree, foundation degree, PGCE etc.);

- all types of course lengths (1-7 years);

- all ages;

- a range of cohorts (2012-17).

The government also allows for bankruptcies and death, and makes additional assumptions about drop-out rates, migration and loan take-up.

Furthermore, as will be explained in Section 2, we use a richer model for simulating graduate earnings and employment profiles, more closely calibrated to earnings levels in the Labour Force Survey (LFS).

Our model calculates the government subsidy to be $23 \%$, i.e. for every $€ 1$ loaned in maintenance and fee loans, the government must pay 23p. If we use the government earnings profiles for the same cohort, rather than ours, under the same assumptions, we get the same mean subsidy of $23 p$ for every $£ 1$ loaned. However, there are significant differences across the distribution of lifetime earnings in the level of subsidies using the two different sets of earnings profiles even though the mean subsidy is the same. ${ }^{1}$ The government figures suggest a subsidy of around $26 \%$ once differences in degree types, course length, student age, cohorts and take-up are taken into account. ${ }^{2}$

\footnotetext{
${ }^{1}$ We have a much lower variance in lifetime earnings than the government profiles.

${ }^{2}$ Unfortunately, we are not in a position to model these complications, but the fact that we cannot model them suggests that our estimates of the government subsidy may be slightly on the low side in this report; however, the differences are not large.
} 


\section{Contents}

Executive summary

1. Introduction

2. Simulating the lifetime earnings of future graduates and the subsidy per graduate

2.1 Lifetime earnings simulations

2.2 Average student subsidies

$\begin{array}{ll}3 . & \text { The current system } \\ \end{array}$

4. Key findings 14

4.1 Charging a real interest rate on loans $\quad 14$

$\begin{array}{ll}4.2 \text { Raising the tuition fee cap } & 19\end{array}$

4.3 The impact of behaviour change $\quad 22$

4.4 Altering other parameters of the student loan system: the loan repayment rate, debt write-off and the repayment threshold 23

$\begin{array}{ll}4.5 \text { Offering students an up-front discount } & 31\end{array}$

5. The balance between public and private contributions 32

6. Conclusions 35

$\begin{array}{ll}\text { Appendix } & 36\end{array}$

$\begin{array}{ll}\text { Technical appendix } & 42\end{array}$ 


\section{Executive summary}

The system of higher education finance in England is currently under formal independent review. In this report, we have attempted to highlight some of the trade-offs that would be involved in reforming the current system of fees and loans applying to full-time undergraduate study.

All our analysis is based on simulations of the lifetime earnings of a single cohort of graduates who are projected to enter full-time undergraduate higher education in 2011 and to graduate in 2014 after three years of study, at the age of 22 in their first year after graduation. We assume all eligible students fully take up their entitlement to loans and fees.

Our analysis shows, in summary, the following:

\section{The current system}

- Under the current maintenance and fee loan system, we simulate the average taxpayer subsidy to be $23 \%$ - in other words, for every $f 1$ loaned in the form of maintenance and fee loans, the government must pay $23 p$. Given an average debt level for a graduate of a three-year undergraduate degree of $£ 20,900$, this amounts to a taxpayer subsidy of $£ 4,800$ per graduate. The amount of this subsidy varies according to graduate lifetime earnings, with the lowest-earning graduates receiving the highest subsidy. If some students do not take up loans, then the overall government subsidy per student will, by definition, be lower. (Sections 2 and 3 )

\section{Charging a positive real interest rate on loans}

- If the government were to charge an interest rate on loans equal to the government's cost of borrowing (2.2\%), this would save the taxpayer money. On average, the subsidy would fall from $23 p$ per $f 1$ loaned, to $10 p$ per $f 1$ loaned. The remaining subsidy would arise because all student debts are written off after 25 years. (Section 4.1)

- The savings generated from charging this interest rate on loans would be highest among graduates in the middle of the graduate lifetime income distribution (around the $10^{\text {th }}$ to $30^{\text {th }}$ percentiles for men and the $60^{\text {th }}$ to $70^{\text {th }}$ for women). This is because these graduates do not benefit from the debt write-off subsidy, but hold onto their loans for a longer period, so benefit most from the interest subsidy. (Section 4.1)

- Under our simulations, the break-even interest rate - i.e. the rate the government would have to charge in order to have a zero-cost system - is around $3.45 \%$. Interest rates higher than this would, assuming graduates did not change their repayment behaviour, be profitable to the exchequer. (Section 4.1) 


\section{Raising the tuition fee cap}

- If the government were to raise the fee cap - and provide a fee loan for the same amount - this would cost the taxpayer money. This occurs mainly because an increasing number of graduates will reach the 25-year threshold without having paid off the full value of their loan. Any further increase in fees cannot increase the burden of payments to these graduates, and instead the taxpayer would effectively have to cover the entire additional cost. (Section 4.2)

- For example, if the average tuition fee rose to $£ 5,000$, the average loan subsidy would increase from $£ 4,800$ per graduate to $£ 6,900$ per graduate. This cost could be reduced by increasing interest rates in conjunction with increasing fees; for example, charging an interest rate of $2.2 \%$ would result in the subsidy falling to $£ 3,600$. (Section 4.2)

- The interest rate required for the loan system to be revenue-neutral rises steeply with the level of the fee. For example, while the 'break-even' real interest rate is $3.45 \%$ at the current fee level of $£ 3,200$, this rises to about $4 \%$ for an average fee level of $£ 5,000$ and to around $4.5 \%$ for an average fee level of $£ 6,000$. (Section 4.2)

\section{Other parameters of the loan system}

- Other parameters of the loan system can also be adjusted to achieve the same subsidy as the current system or a lower one, with or without increasing interest rates and/or fees. Changes can be made, for example, to the repayment rate, the number of years after which debt is written off and/or the threshold at which people start repaying. The government could use different combinations of these parameters in order to save money, or create a revenue-neutral or profitable system. For instance, the government could create a zero-cost system by raising the interest rate to $3.2 \%$ and raising the repayment rate to $11 \%$. But it could also create a revenue-neutral system by raising the repayment rate to $13 \%$ and charging a 3\% interest rate. There are many other combinations that the government could use to alter its costs. We have produced a set of indifference curves which can be consulted for this purpose. (Section 4.4 and Appendix)

- However, it is vital to consider the distributional consequences for different types of graduates when changing these parameters. More regressive ways of raising revenue include increasing the repayment rate, lowering the repayment threshold and/or increasing the debt write-off period beyond 25 years. (Section 4.4) 
- More progressive ways that the taxpayer could save money using the existing parameters include increasing the interest rate in conjunction with lowering the loan repayment rate, and/or making graduates pay for a further period of time after they have paid off the full balance of their loans. (Section 4.4)

- For example, a zero-subsidy system could be achieved by imposing a $5 \%$ real interest rate and a $5.8 \%$ repayment rate, and this would give the biggest taxpayer subsidy to the lowest graduate earners. However, this would only result in a zero overall subsidy on the assumption that the highest-earning graduates do not choose to pay off their loans faster than dictated by the income-contingent repayment schedule (which would save them money and cost the government money). (Section 4.4)

- Another strategy could be to compulsorily extend the length of the repayment period for a further two years after graduates have paid off their loans - while still preserving the 25-year debt write-off period. This could offset some of the effects of early repayment by high-earning graduates and is also quite progressive. (Section 4.4)

- Alternatively, the government could choose to introduce new features to the current system in order to save money. One such example is to offer students a discount for up-front payment of fees or early repayment of their loans. In order for such a system to be profitable for the exchequer, however, graduates who would actually lose out financially by taking up the discount would need to be induced to do so. (Section 4.5)

\section{Increasing graduate contributions}

- All of the reforms considered in this report involve transfers of money between the private sector (students and graduates), the public sector (taxpayers) and universities. While many scenarios we have considered actually involve an increase in costs to the taxpayer, those that save the taxpayer money increase the cost of going to university for private individuals. (Section 5)

\section{Behavioural changes in response to reforms}

- Increasing the cost of attending university may result in important behavioural change consequences. These could take the form of graduates making overpayments to reduce their debt or students declining to take up loans, or indeed deciding not to participate in university at all. It is essential that policymakers are aware of all these possible changes when they consider different reforms. (Section 4.3) 


\section{Introduction}

The subject of how to finance higher education (HE) has been debated for many years, most recently upon the introduction of top-up fees of up to $£ 3,000$ (in 2006 prices - or around $€ 3,200$ in 2011 prices) per year for students starting full-time undergraduate degree courses in 2006. A key promise made by the Labour government, as part of the reform package, was to run a comprehensive review of the system in 2009 - at which point all full-time undergraduate students in the system would be subject to the $f 3,200$ fee cap. The review, chaired by Lord Browne, is currently underway and will be taking evidence up to May 2010. ${ }^{3}$

Lord Browne has been asked to examine three issues: widening university participation, affordability of higher education for students and the taxpayer, and how to simplify the current system of support. The current system consists of means-tested maintenance grants and loans, and universal fee loans which cover the full value of the $£ 3,200$ fee. Given the current economic circumstances, an extremely important issue arising from the review will be how to ensure the financial sustainability of the system during a period of fiscal constraint. A variety of possible policy changes have been publicly debated, and the most widely discussed include increasing the maximum level of fees - which, if accompanied by an increase in fee loans alone, would involve a rise in the public contribution towards $\mathrm{HE}$ - and/or charging a real interest rate on maintenance and fee loans - which on its own would reduce it.

In this report, we quantitatively evaluate a number of these scenarios, in terms of the impact on costs to the exchequer and of the distributional impact on different types of graduate. One important additional contribution we make is to try to assess the possible behavioural responses to different types of reforms - an issue that is often overlooked when different policy options are analysed.

To help us model the possible impact of alternative reforms, we have produced new simulations of the future lifetime earnings profiles of a cohort of full-time undergraduate university entrants who will be entering the $\mathrm{HE}$

\footnotetext{
${ }^{3}$ The Independent Review of Higher Education Funding and Student Finance, jointly commissioned by the Government and the Opposition, was launched on 9 November 2009. The review is tasked with making recommendations to government on the future of higher education funding and student financial support for full- and part-time undergraduate and postgraduate students.
} 
system in 2011. These simulations build on our previous work in this area ${ }^{4}$ and are based on an improved methodology that allows us to take into account the likely persistence of earnings and employment shocks, arising, for example, from a recession. These earnings profiles allow us to calculate graduates' fee and maintenance loan repayment schedules under a number of different reforms, and therefore to assess the change in costs to the exchequer of changing $\mathrm{HE}$ finance policies, compared with the current system.

We find that potential reforms have quite different consequences for the exchequer and for different types of graduate depending on their position in the earnings distribution. Our key findings reveal:

- Charging an interest rate on loans saves the taxpayer money but generates slightly more savings from males and females in the lower to middle parts of the lifetime earnings distribution than from the highest-earning graduates, since these graduates benefit most from the interest subsidy.

- Increasing the fee cap (where loans are fully extended to cover the fee) costs the taxpayer money, but this cost can be reduced by increasing interest rates in conjunction with increasing fees.

- Other parameters of the loan system can be adjusted to achieve the same subsidy as the current system or a lower one - for example, changes can be made to the repayment rate, the number of years after which debt is written off or the threshold at which people start repaying. We illustrate the ways in which different interest rates and repayment rates can be combined to produce subsidies as desired - but also, crucially, to change the progressivity of the system.

The structure of this report is as follows. Section 2 briefly sets out how we have simulated the lifetime earnings of future graduates, Section 3 describes the current system of fee and maintenance loans, the costs to the exchequer of this system and the distributional costs of the system according to graduate earnings, and Section 4 presents the key findings. Section 5 examines the scenarios in a different way, by illustrating the resulting balance of payments between public and private contributors. Section 6 concludes.

\footnotetext{
${ }^{4}$ See L. Dearden, E. Fitzsimons, A. Goodman and G. Kaplan, 'Higher education funding reforms in England: the distributional effects and the shifting balance of costs', Economic Journal, 2008, 118, F100-F125.
} 


\section{Simulating the lifetime earnings of future graduates and the subsidy per graduate}

\subsection{Lifetime earnings simulations}

Our analysis is based on simulations of artificial earnings paths for the cohort of full-time undergraduates graduating in 2014. In order to generate these simulations, we estimated a rich statistical model for earnings and employment dynamics using two large data sets that contain survey information on British graduates' labour market outcomes - the Labour Force Survey (LFS) and the British Household Panel Survey (BHPS). The statistical model generates cross-sectional earnings distributions that are consistent with the high-quality cross-sectional data from the LFS. Transitions between employment and non-employment, and year-on-year earnings fluctuations, are consistent with the dynamics observed in the BHPS.

We make specific assumptions about future earnings growth and loan takeup, based on the macroeconomic forecasts contained in the IFS Green Budget $2010 .{ }^{5}$ In particular, we assume an economy-wide real earnings growth rate of $1.8 \%$ between 2008 and 2014, followed by a return to the long-run growth rate of $2 \%$. This central scenario incorporates a $4.5 \%$ reduction in real earnings growth relative to trend between mid-2007 and mid-2010. The short-term reduction in earnings growth reflects poor labour market conditions associated with the current recession. This real earnings growth is in addition to expected earnings growth associated with the accumulation of labour market experience over these years. We also perform all calculations based on a more optimistic, and a more pessimistic, earnings growth scenario. The results from these alternative scenarios are presented in the Appendix.

We assume full take-up of maintenance and fee loans, though it is straightforward to calculate the average subsidy under different take-up assumptions. ${ }^{6}$

\subsection{Average student subsidies}

Having access to a set of simulated earnings profiles that reflect the entire distribution of graduates' possible lifetime earnings paths is crucial for

\footnotetext{
${ }^{5}$ See appendix A of R. Chote, C. Emmerson and J. Shaw (eds), The IFS Green Budget: February 2010, Commentary 112, Institute for Fiscal Studies, London, 2010 (http://www.ifs.org.uk/publications/4732).

${ }^{6}$ For example, if both maintenance and fee loan take-up were estimated to be $80 \%$ (and take-up was assumed to be random across the population with both fee and maintenance loans taken up by the same students), the subsidy could be calculated by simply multiplying the estimate by 0.8 .
} 
assessing the likely impacts of policy changes. Only focusing on specific 'example' graduates or restricting attention to the path of average graduate earnings can lead to potentially misleading inferences. This is best seen by considering our estimate of the average public subsidy on student loans, calculated from the entire distribution of earnings paths. We estimate this number to be approximately $23 \%$. However, if one were to focus only on a graduate earning average earnings at each age, one would conclude that the subsidy is around $18 \%$. The lower subsidy results because the earnings distribution is right-skewed, i.e. there are more people concentrated in the bottom of the earnings distribution than the top, which means that mean earnings for men and women are higher than median earnings (the earnings of someone exactly in the middle of the entire male or female earnings distribution). Hence, ignoring the full distribution of possible earnings paths understates the importance of individuals with low lifetime earnings for the overall subsidy.

Not only does the distribution of lifetime earnings matter, but the timing of income receipts during the lifetime matters. To see why, consider an extreme example where two graduates have the same total lifetime income, but one has high earnings during his/her 20s and 30s, while the other only enters the labour force much later, perhaps after having children. In this case, the second graduate is far more likely to benefit from the 25-year debt write-off than is the first, even though their total lifetime earnings are the same. Our simulations take these differences into account, by allowing for all plausible paths of earnings over the lifetime.

It is clear from government sources that our estimates of the subsidy per student are lower than government estimates. As described in the Preface, they reflect a different modelling approach to simulating future earnings paths for graduates as well as a more heterogeneous student population and different assumptions about drop-out rates, migration and loan take-up.

\section{The current system}

In September 2006, a new system of HE funding came into operation in England. This saw large increases in fees, up to $£ 3,000$ (at 2006 prices $-£ 3,200$ at 2011 prices) payable by all graduates of full-time undergraduate degrees. Instead of being payable up front, all fees became deferrable until after graduation, with loans available at a zero real interest rate, repayable through the tax system according to income (at $9 \%$ above a threshold of $f 15,000$ ). A zero real interest rate is charged on loans, and all loans are written off after 25 years. In addition to these arrangements for student support, the taxpayer continues to make a significant ongoing contribution to undergraduate 
teaching through the centrally allocated HEFCE grant. Further details, including changes to maintenance loans, are set out in Dearden et al. (2008). ${ }^{7}$

The intention behind the reforms was to ensure (i) that a greater share of the costs of $\mathrm{HE}$ be borne by graduates, the main beneficiaries of $\mathrm{HE}$; (ii) that the system include an insurance element to protect graduates against low realised returns from $\mathrm{HE}$; and (iii) that universities see increased funding per head.

Despite the increased contribution by graduates resulting from these reforms, a substantial proportion of the private fee revenue still effectively comes from the public purse in the form of loan subsidies, which arise both because of the zero real interest rate charged on the new fee loans and because of the provision for debt write-off after 25 years.

Figures 1-3 show respectively the present value of debt repayments that graduates are expected to make (i.e. net of any subsidies they gain from the zero real interest rate and debt write-off), the taxpayer subsidy (expressed as a percentage of the original loan) that graduates can expect to receive under the current system, and the number of years over which graduates can be expected to repay their loans. The charts show how the value of each of these differs across the distribution of graduates' lifetime earnings. In all cases, we assume an initial debt level of $£ 20,900$ (at 2011 prices), which represents an estimate of the average total debt that an undergraduate student will incur over a three-year degree course. ${ }^{8,9}$

The charts show these key statistics for the whole of our sample, and also for males and females separately.

Note that in order to calculate net present values of debt repayments and the value of taxpayer subsidies, we assume a real discount rate of $2.2 \%$ per year (this follows the government's present convention for discounting; see DIUS Annual Report 2009, annex 1, table 11, for more details).

\footnotetext{
${ }^{7}$ L. Dearden, E. Fitzsimons, A. Goodman and G. Kaplan, 'Higher education funding reforms in England: the distributional effects and the shifting balance of costs', Economic Journal, 2008, 118, F100-F125.

${ }^{8}$ We assume for all calculations that $100 \%$ of students take up the average fee and maintenance loan (see Student Loans Company Statistical First Release 06/2009, table 4) each year, for a total of three years. See the Technical Appendix for further details of the assumptions made.

${ }^{9}$ Note that all figures are expressed in 2011 prices and are rounded to the nearest f100.
} 
Figure 1. Current system: net present value of graduate repayments

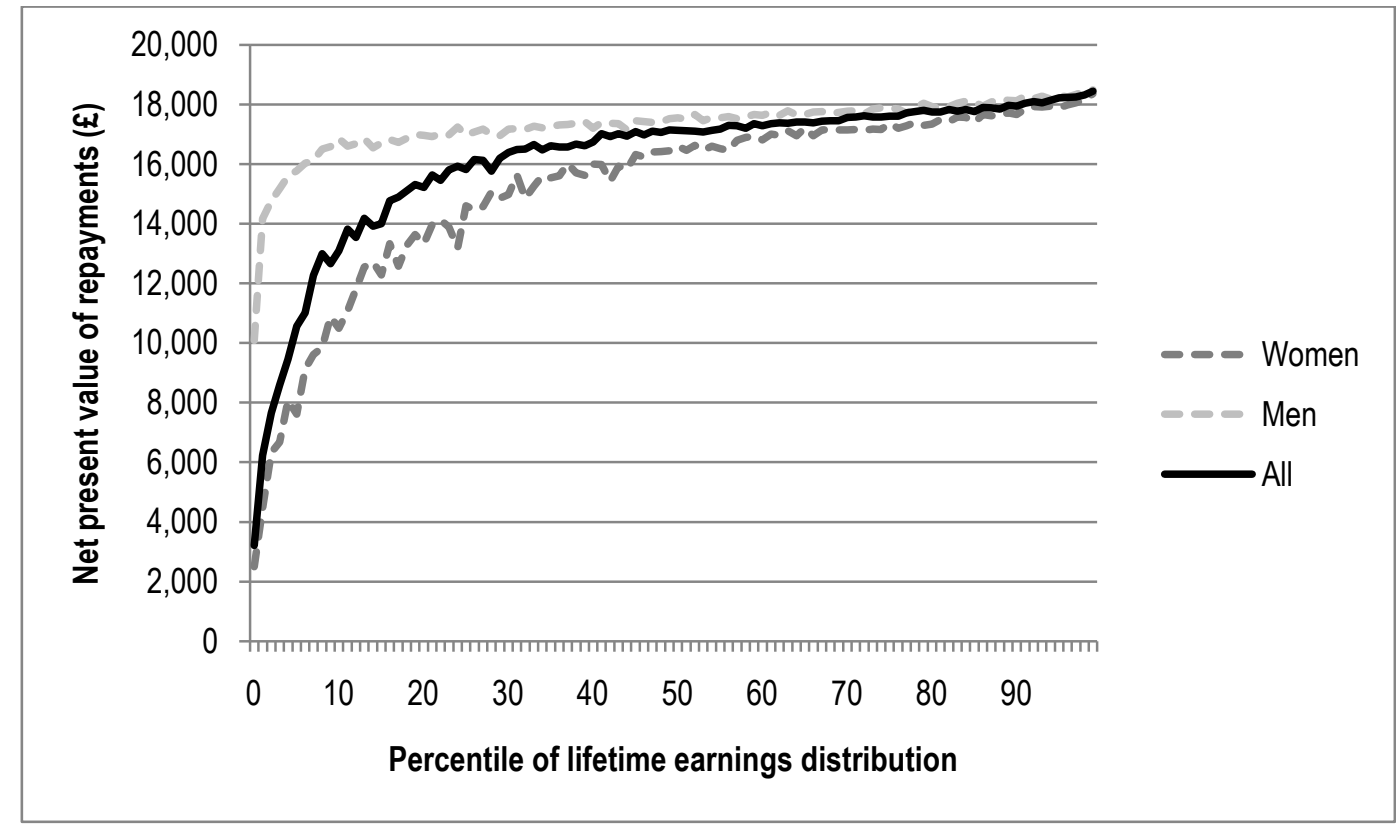

Note: Estimates for males' and females' combined lifetime earnings percentiles are based on all graduates combined, while for males and for females, lifetime earnings percentiles are gender specific, i.e. earners at the $10^{\text {th }}$ percentile of males earn more than those at the $10^{\text {th }}$ percentile of females.

Figure 2. Current system: taxpayer subsidy as a percentage of loan

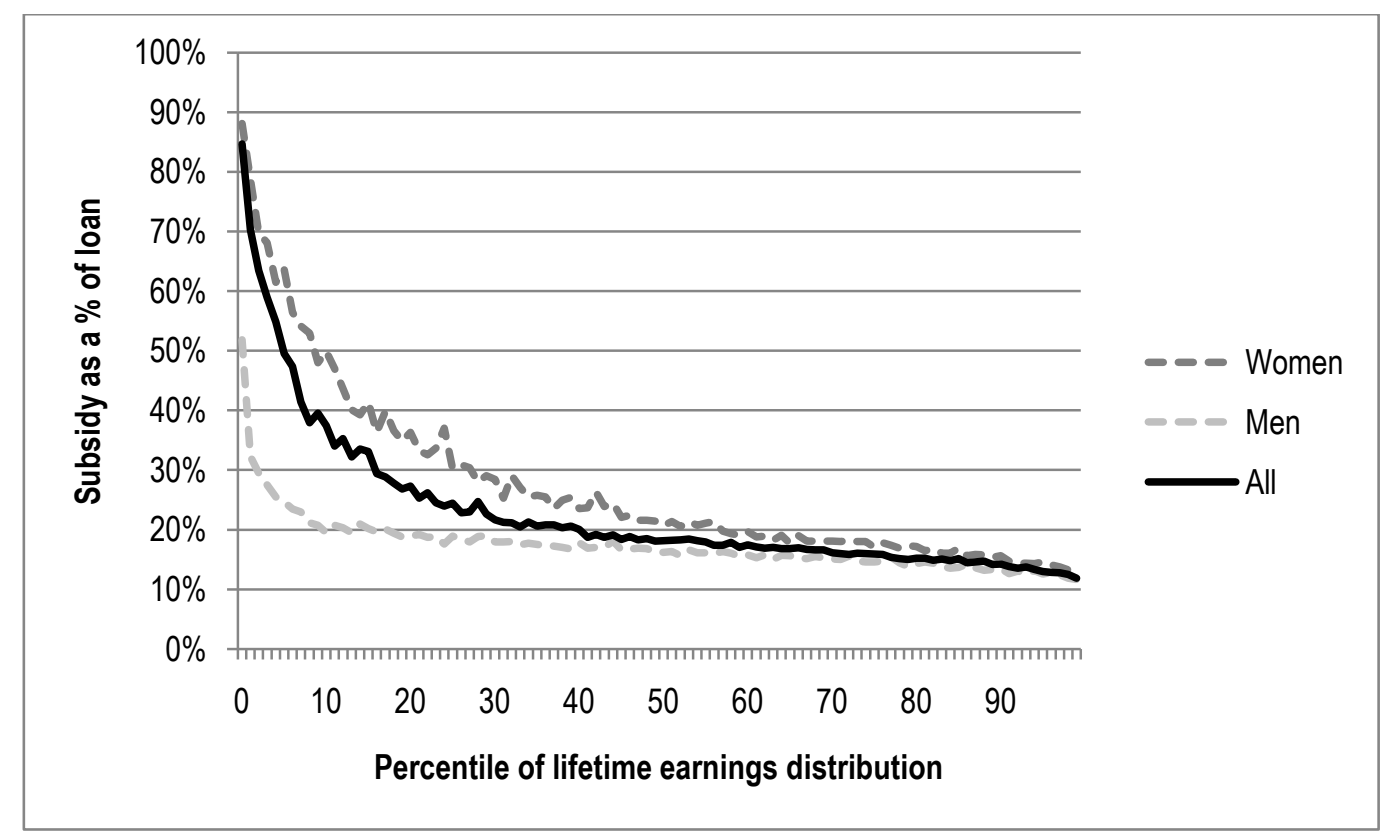

Note: Estimates for males' and females' combined lifetime earnings percentiles are based on all graduates combined, while for males and for females, lifetime earnings percentiles are gender specific, i.e. earners at the $10^{\text {th }}$ percentile of males earn more than those at the $10^{\text {th }}$ percentile of females. 
Figure 3. Current system: years to repay loan

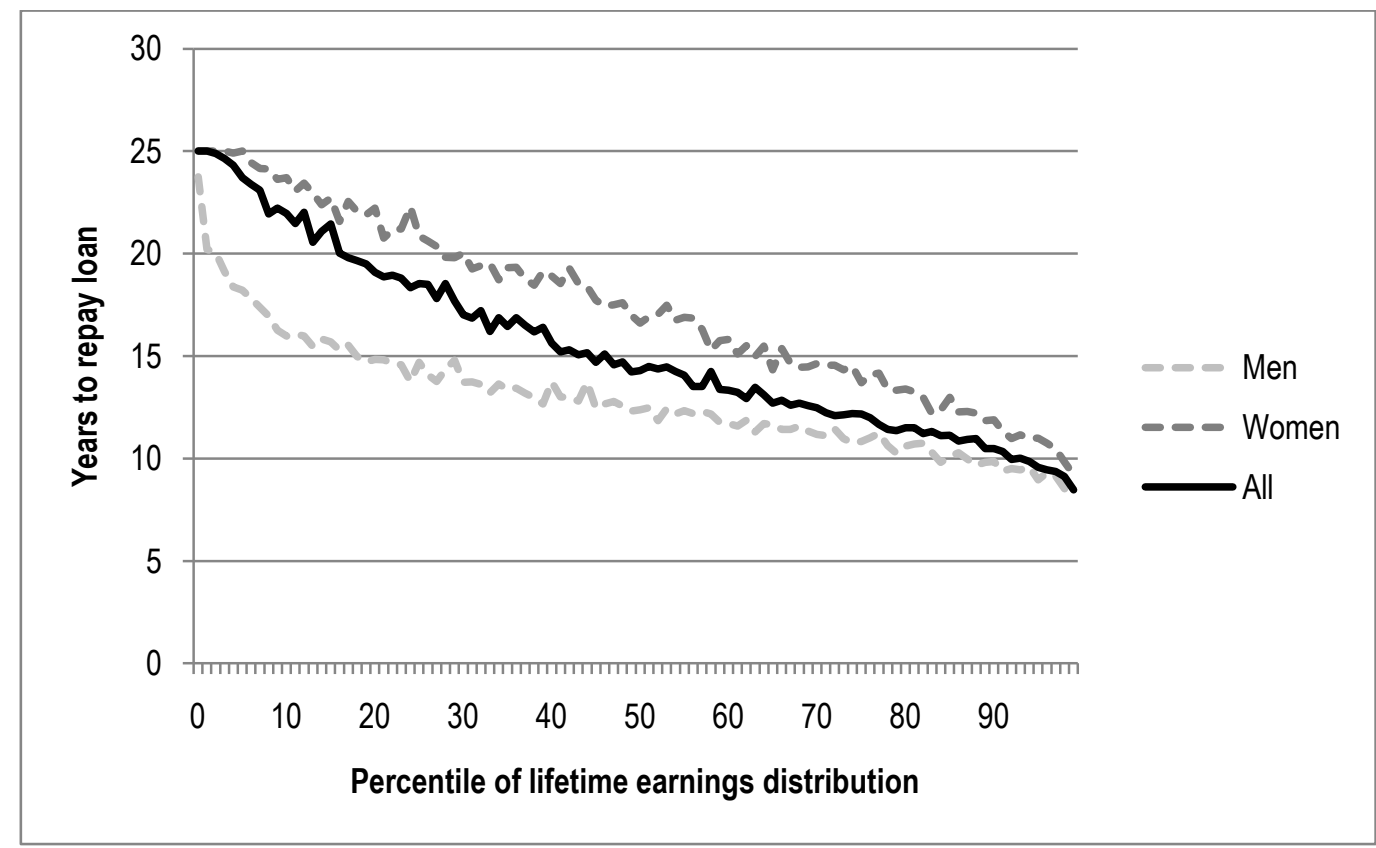

Note: Estimates for males' and females' combined lifetime earnings percentiles are based on all graduates combined, while for males and for females, lifetime earnings percentiles are gender specific, i.e. earners at the $10^{\text {th }}$ percentile of males earn more than those at the $10^{\text {th }}$ percentile of females.

For a given level of debt on graduation, graduates with lower lifetime earnings will eventually repay less of their debt, whilst higher earners will repay more (Figure 1). This feature of the income-contingent loan system arises due to the interest subsidy and debt write-off built into its design.

By the same token, the value of the government subsidy (expressed as a percentage of the face value of the loan in Figure 2) is strongly decreasing in income, ranging from nearly $90 \%$ for the lowest lifetime-earning women to less than $15 \%$ for the highest-earning women (with the average across all women at around $27 \%$ ). For men, the range of taxpayer subsidy is narrower from just over $50 \%$ for the lowest earners to $12 \%$ for the highest earners (with the average subsidy at around $17 \%)$.

The number of years taken to repay (Figure 3) is also decreasing in lifetime earnings - ranging from 25 years for the lowest earners (at which point all outstanding debt will be written off) to less than 10 years for the highest earners. The average time for repayment will be around 17 years for women and around 13 years for men. Around $25 \%$ of women can expect to have some debt written off, with their repayment capped at the 25-year cut-off, whilst this is the case for only around $3 \%$ of graduate men. These men and women are scattered throughout the earnings distribution (many high lifetime earners benefit from debt write-off depending on the timing of their earnings - for example, if an individual has low earnings throughout most of their working 
life, but a period of very high earnings towards the end, they may still benefit from the 25-year write-off). In fact, there are individuals benefiting from debt write-off at up to the $70^{\text {th }}$ percentile for women and the $20^{\text {th }}$ percentile for men.

These results all highlight the fact that the longer the loan is held by a graduate, the bigger is the taxpayer contribution to the repayment of that loan. This, of course, runs counter to a commonly-held notion that holding graduate debt for a long time is an indication of the 'heavy burden' of that debt.

\section{Key findings}

\subsection{Charging a real interest rate on loans}

As described in Section 3, under the current maintenance and fee loan system, loans are charged at a zero real rate of interest. In other words, graduates only pay interest equal to the rate of inflation. This represents a large interest subsidy, since the exchequer itself must pay interest on this money.

One of the most frequently-cited potential policy changes that would save the taxpayer money involves removing this interest subsidy and charging a real interest rate on loans.

Figure 4 shows the potential subsidy or profit borne by the exchequer under a range of potential real interest rates. All figures are expressed as the subsidy per student in total for a three-year course.

Figure 4. Subsidy/Profit per student at different levels of interest rate

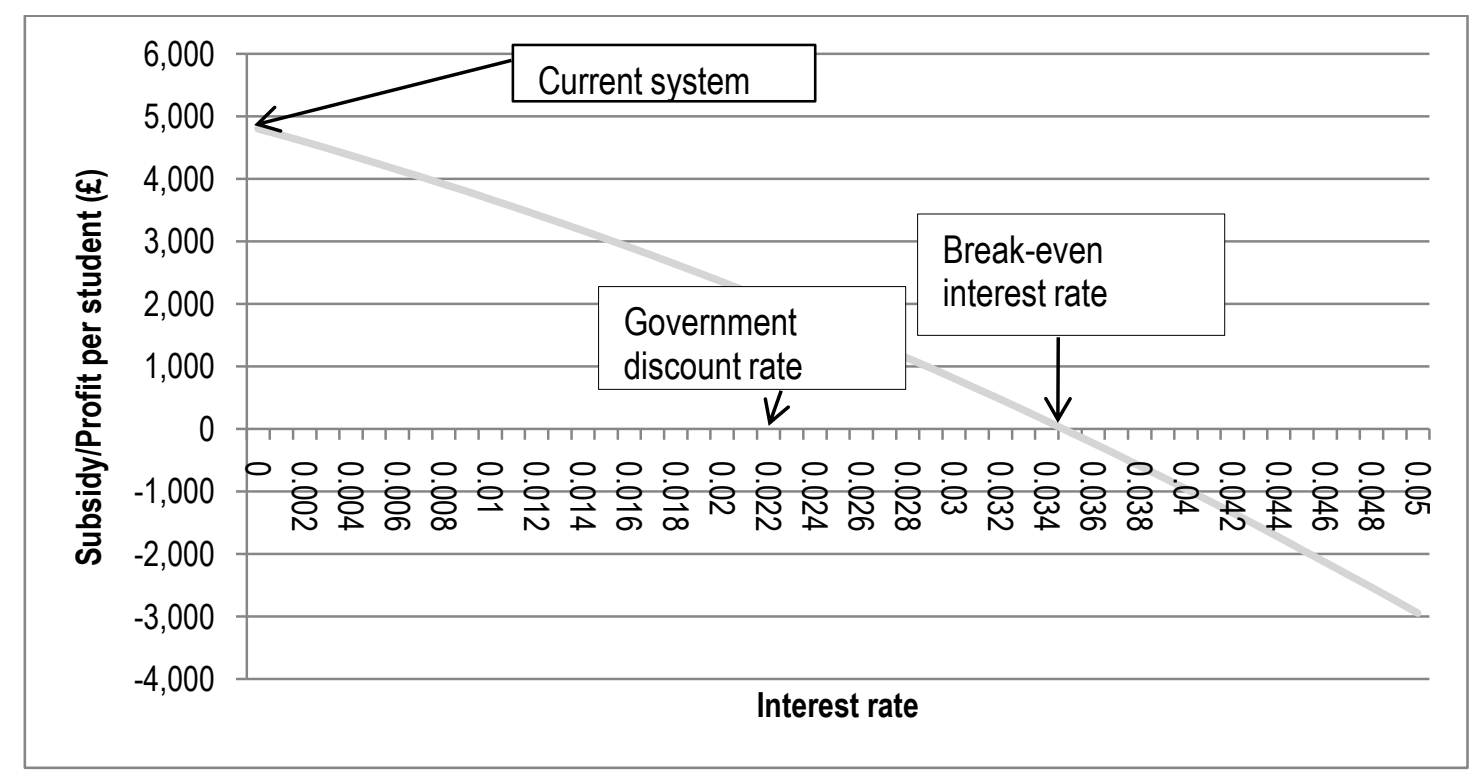


Under the current system of zero real interest rates, our estimates suggest that the exchequer pays an average subsidy of $£ 4,800$ per student. This figure comprises two components: the interest subsidy - the cost to the government of paying the interest on the loan on behalf of the student - and the write-off subsidy - the amount of debt that is left unpaid by each graduate after 25 years, at which point all debt is written off as a taxpayer loss.

As Figure 4 also illustrates, as the level of the real interest rate rises, the government subsidy falls, and eventually, at an interest rate of around $3.45 \%$, the average subsidy per student is zero. Interest rates higher than this result in a profit for the government, as, on average, the net present value of graduate repayments is greater than the value of their initial debt. Therefore, if the exchequer wanted to neutralise the costs of the loan element of the HE system, it could do so by charging an interest rate of $3.45 \%$.

However, while this may be desirable from a savings point of view, charging a real interest rate on loans would have important consequences for different types of graduates, depending on their lifetime earnings profile.

To illustrate this, Figure 5 presents the possible distributional consequences of charging a real interest rate. It shows the value of the subsidy to graduates at different points in the graduate lifetime earnings distribution under the current system of zero real interest rates, and if there were a real interest rate of $2.2 \%$ on student fee and maintenance loans. We have chosen $2.2 \%$ as an example real interest rate because this is the discount rate used in official figures for calculating the government cost of borrowing relating to these loans (this is also illustrated in Figure 4). Indeed, this interest rate would make the system cost-neutral if there were no provision for debt write-off after a fixed period.

As Figure 5 illustrates, if interest rates were raised to equal the government cost of borrowing, then the remaining subsidy would be purely as a result of the 25-year debt write-off provision, since there would be no interest subsidy. For men, the debt write-off subsidy is relatively low, and only those graduates in the bottom $10-20 \%$ of the male graduate lifetime earnings distribution benefit from this subsidy. As lifetime earnings increase, male graduates do not benefit from the write-off subsidy, since they earn sufficient amounts to be able to repay their loans in full. However, as Figure 5 illustrates, male graduates across the distribution would lose out from a policy that introduced a $2.2 \%$ real interest rate. 
Figure 5. Taxpayer subsidy under the current system and a $2.2 \%$ interest rate
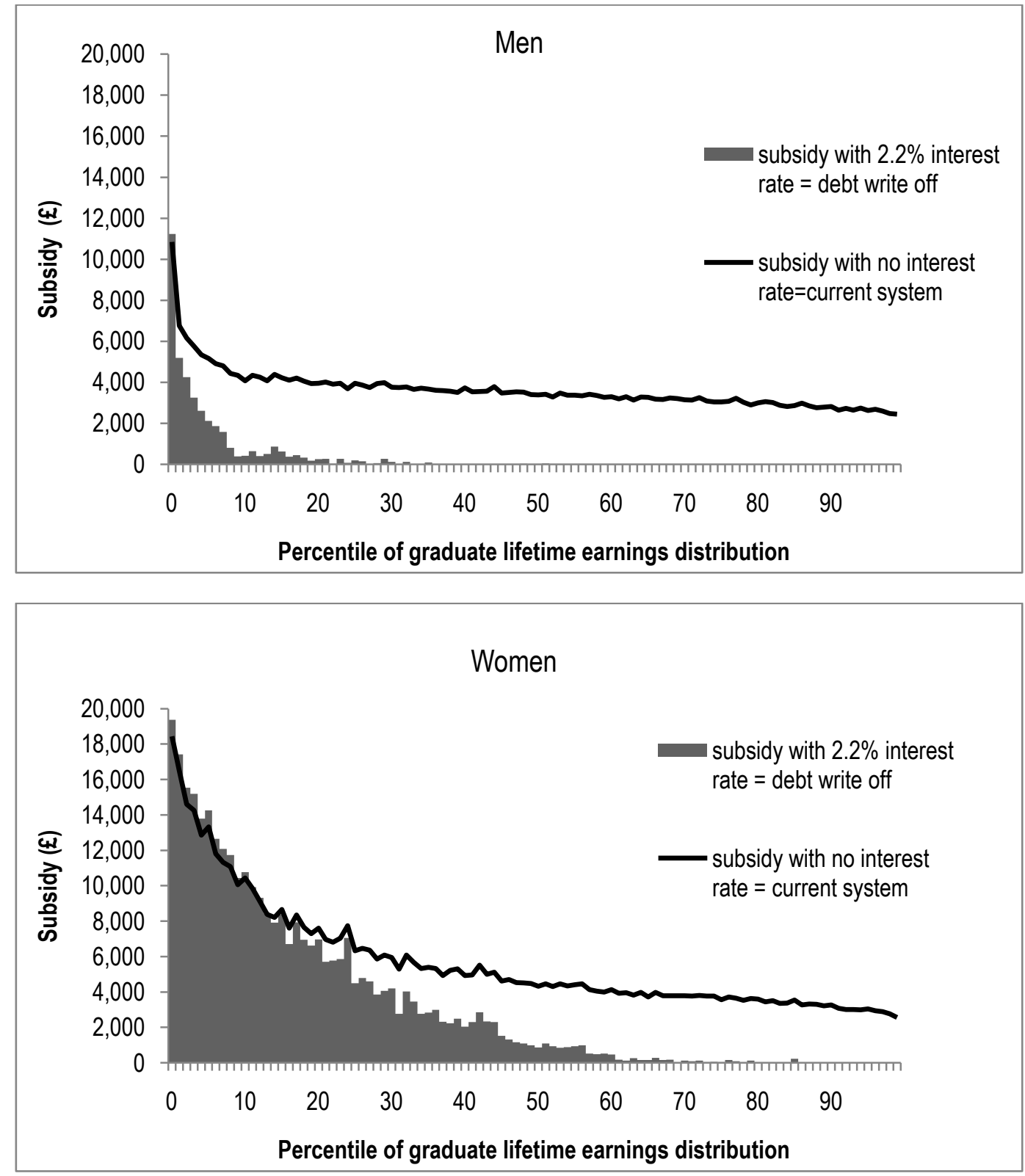

Figure 6 illustrates the resulting savings to the exchequer if the interest subsidy were completely removed. Again looking at men, it can be seen that this policy would result in average savings to the exchequer from men at all but the very lowest point in the earnings distribution. The subsidy across male graduates would fall from an average of $17 p$ per $f 1$ of debt, to only 1.9p per $f 1$ loaned. The savings would amount to $£ 3,200$ per male graduate of a fulltime undergraduate degree. 
Figure 6. Savings resulting from introducing a $2.2 \%$ interest rate
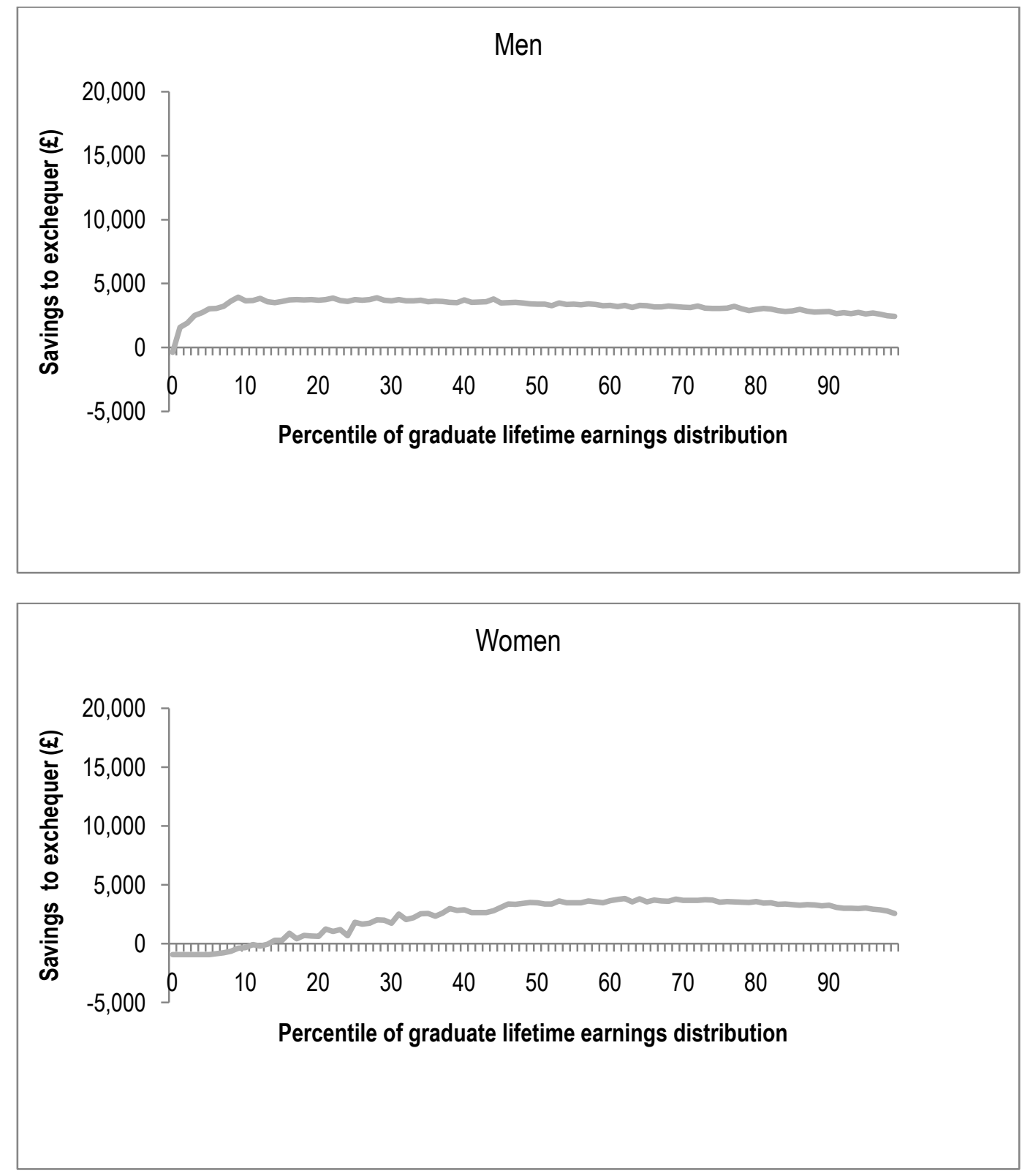

While the savings are fairly uniform across male graduates, slightly more savings are generated from male graduates at lower-to-middle points in the earnings distribution (around the $10^{\text {th }}$ to $30^{\text {th }}$ percentiles). These graduates have earnings such that they do not benefit much or at all from the write-off period, but they do benefit greatly from the interest subsidy. Thus, an increase in interest rates would cause them to be worse off than higherearning graduates.

The story for female graduates is quite different. Women, by virtue of having lower lifetime earnings, benefit far more from the write-off subsidy. Some female graduates up to the $70^{\text {th }}$ percentile of the female graduate lifetime 
earnings distribution do not fully repay their loans before 25 years and therefore benefit from the debt write-off subsidy. Were the interest subsidy to be removed, these lower earners would still be financially protected by the debt write-off subsidy, but many would lose out from the removal of the interest subsidy. The impact of removing the subsidy is slightly more progressive for women than for men. The greatest savings would be generated from female graduates in the $60^{\text {th }}$ to $70^{\text {th }}$ percentiles of the female graduate lifetime earnings distribution. In sum, the average subsidy for each female graduate would fall from $27 p$ per $£ 1$ of debt to $16 p$ per $£ 1$ of debt. The savings would amount to an average of $£ 2,300$ per female graduate.

In total (taking men and women together), therefore, raising interest rates to $2.2 \%$ would significantly shift the costs of student loans from the taxpayer to graduates. The average subsidy would fall from $23 p$ per $£ 1$ of graduate debt to only $10 p$ per $£ 1$ - a government saving of $£ 2,700$ per head.

As explained previously, the government may instead want to choose an interest rate that causes the system to be revenue-neutral. As illustrated in Figure 4 , an interest rate of around $3.45 \%$ should achieve this. Again, there would be important distributional consequences to increasing interest rates to such a level.

Figure 7. Subsidy/Profit under a 3.5\% interest rate, a $2.2 \%$ interest rate and the current system

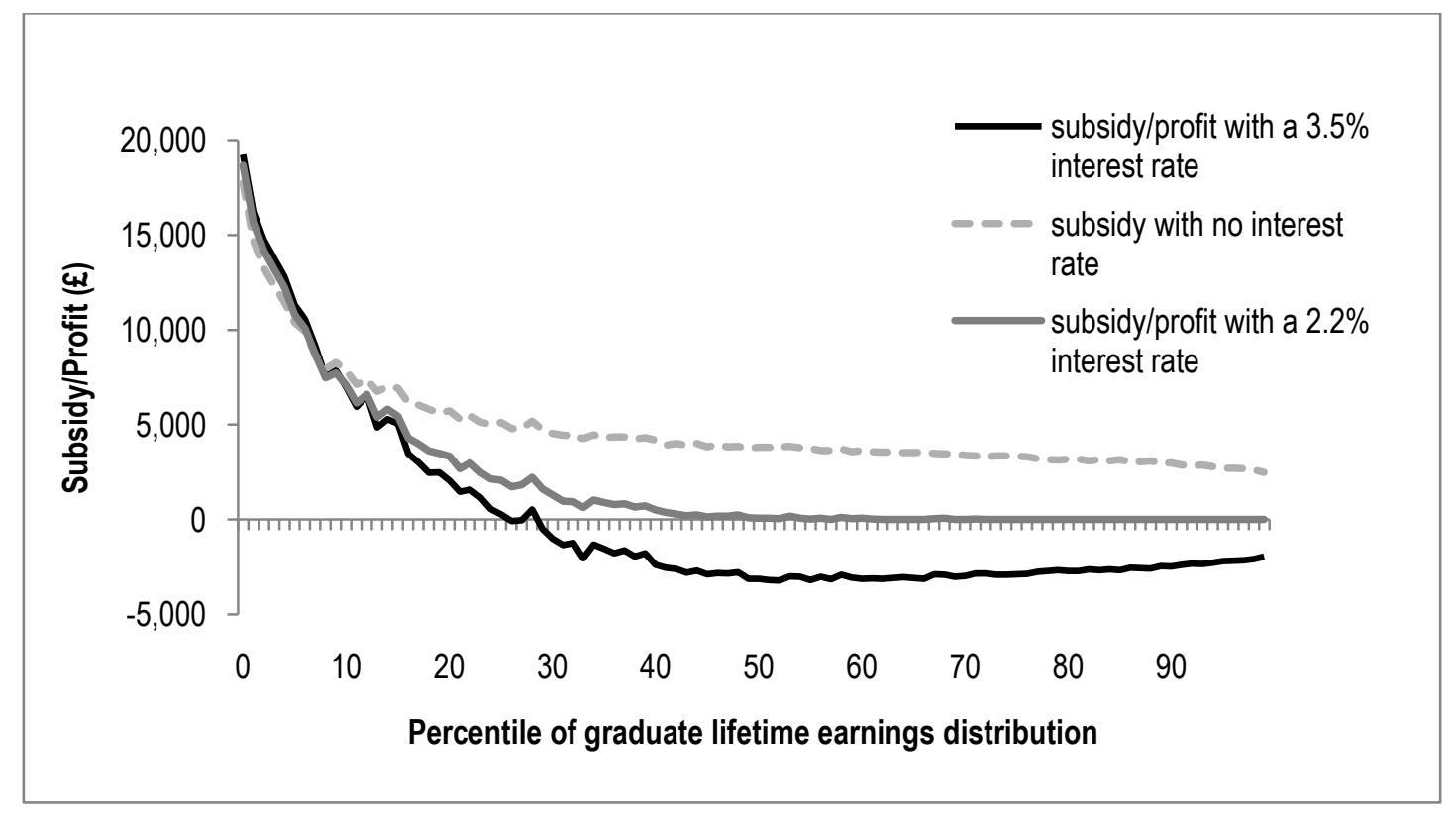

Figure 7 illustrates this, by showing the subsidy for a system with a $3.5 \%$ real interest rate (which is roughly the revenue-neutral rate), alongside the current system and a system with a $2.2 \%$ real interest rate. In the current system of 
zero real interest rates, all graduates receive some subsidy. In a system with a $2.2 \%$ real interest rate, graduates from around the $50^{\text {th }}$ graduate earnings percentile and above would receive no subsidy at all; the minimum value of the subsidy is zero. At an interest rate of $3.5 \%$, graduates from around the $25^{\text {th }}$ percentile of graduate earnings onward actually make a net contribution to the exchequer, while those earning below the $25^{\text {th }}$ percentile still receive a government subsidy. Overall, this combination of under- and over-payments would result in a small overall profit for the exchequer of $0.2 \mathrm{p}$ per $£ 1$ loaned (or an average of $£ 100$ overpaid by each graduate).

\section{Summary}

Table 1 provides a summary of our estimates of the exchequer subsidy per $£ 1$ loaned under each of the systems discussed above. As can be seen from the table, charging higher interest reduces the taxpayer subsidy and can, for sufficiently high interest rates, involve a taxpayer profit if other parameters and behaviour remain unchanged. We look at the issue of interest rates again in Section 4.4.

Table 1. Subsidy/Profit per $£ 1$ of debt, increasing interest rates

\begin{tabular}{l|c}
\hline \hline & $\begin{array}{c}\text { Subsidy/Profit } \\
\text { per f1 loaned }\end{array}$ \\
\hline Current system & $23 p$ \\
$2.2 \%$ interest rate & $10 p$ \\
$3.5 \%$ interest rate & $-0.2 p$ \\
\hline \hline
\end{tabular}

\subsection{Raising the tuition fee cap}

In 2006, a variable, deferred tuition fee was introduced, with the maximum fee capped at $£ 3,000$ in 2006 prices (or $£ 3,200$ at 2011 prices). In practice, almost all universities decided to charge students the maximum fee, and it is possible that the fee cap will be raised further in the future.

Here, we assess the impact of possible increases in fees on government spending and on graduate repayments, under a range of different loan interest rates and under the assumption that fee loans would be extended to fully cover the increased fees. ${ }^{10}$

\footnotetext{
${ }^{10}$ While we have assumed that any fee increase would be fully covered by a fee loan, other options have been suggested by academic and policy bodies, such as removing government-subsidised loans in favour of private sector loans for high-income students (e.g. A. Fazackerley and J. Chant, More Fees Please? The Future of University Fees for Undergraduate Students, Policy Exchange, London, 2010, http://www.policyexchange.org.uk/images/publications/pdfs/PX_More_Fees_Please WEB.pdf). We have not considered such policies since we believe it would be unfeasible
} 
Figure 8 illustrates the government subsidy that would result at different average fee levels (we consider only the average fee level, since we have no way of systematically attributing differing fee levels that might be charged by universities to graduates earning different amounts). As it is possible that interest rates on loans would also be charged alongside a possible increase in the fee cap, the chart also shows how the subsidy would change at different levels of interest rates.

Figure 8. Subsidy/Profit per student at different average fee levels and different interest rates

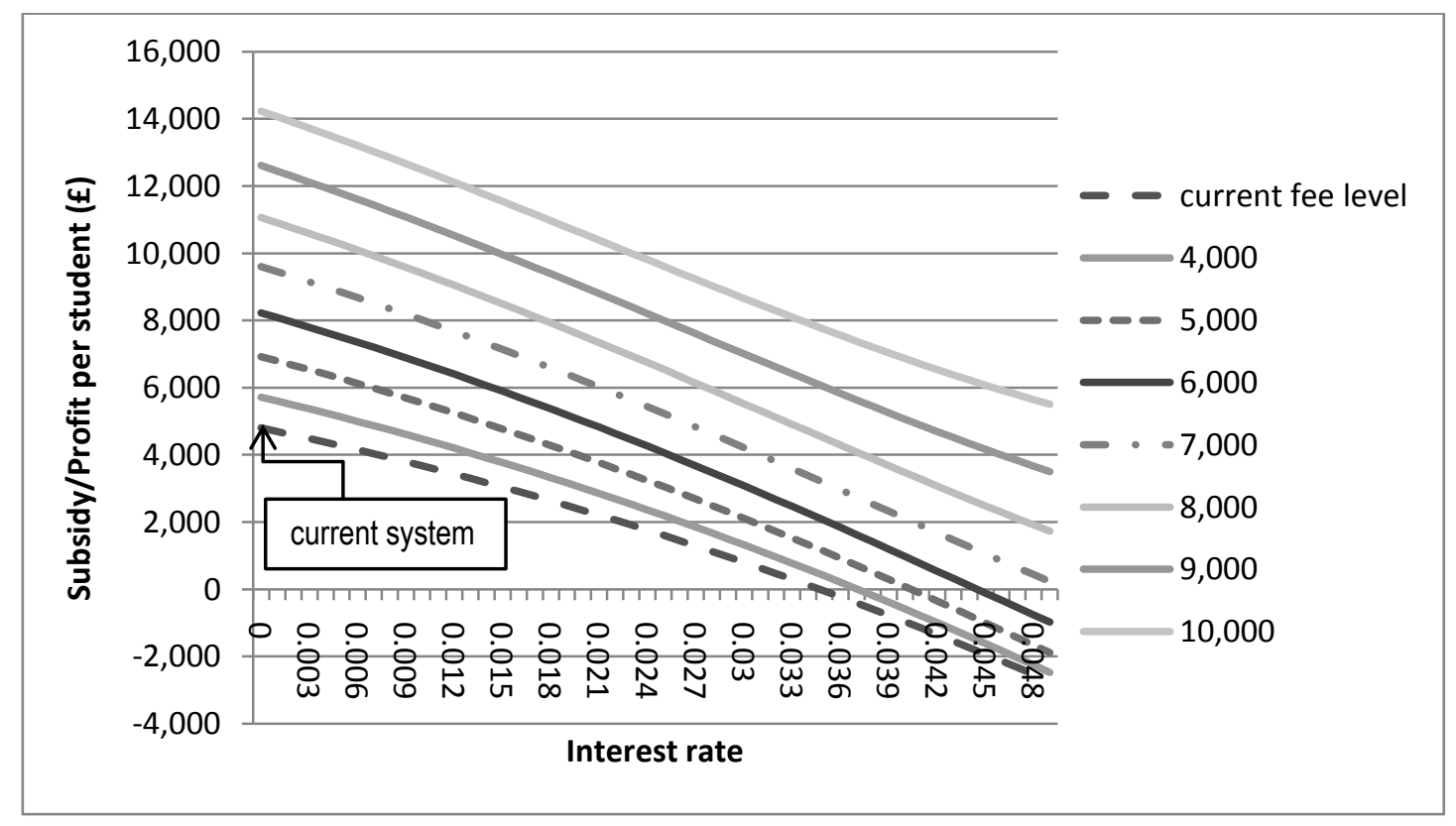

In a system with zero real interest rates, an increase in fees would result in an increase in the taxpayer subsidy (this can be seen at the far left-hand side of Figure 8 , where interest rates are zero). For example, if the fee cap were increased so that the average fee was $£ 5,000$, the government subsidy would go from $f 4,800$ per graduate to $f 6,900$ - a net cost of $f 2,100$ per graduate. This arises both because of the interest subsidy and because of the debt writeoff - since the cost to the taxpayer of each of these increases with higher debt. Therefore, increasing the fee cap without altering the current repayment system would result in an increase in the costs of student support funded by the taxpayer.

One way of reducing this cost would be to increase the interest rate on loans at the same time as increasing fees. The downward slope of the lines drawn in

for even high-income students to obtain large loans from the private sector (or from their parents). 
Figure 8 highlights the fact that at each fee level, the taxpayer cost is lower the higher the interest rate charged. Under a $£ 5,000$ average fee, for example, it would require a $1.5 \%$ real interest rate to ensure that the taxpayer subsidy would not need to increase beyond the $£ 4,800$ subsidy implied by the current system.

On the other hand, the interest rate required for the loan system to be revenue-neutral rises steeply with the level of the fee. For example, while the 'break-even' real interest rate is $3.45 \%$ when the fee cap is $£ 3,200$, this rises to about $4 \%$ for an average fee level of $£ 5,000$ and to around $4.5 \%$ for an average fee level of $£ 6,000$.

The interest rate required to break even rises so sharply with the level of the fee because of the escalating costs of debt write-off as fees rise. These in turn arise simply because an increasing number of graduates will reach the 25 -year threshold without having paid off the full value of their loan. Any further increase in fees cannot increase the burden of payments to these graduates, and instead the taxpayer would effectively have to cover the entire additional cost.

Table 2 summarises a few of the points from Figure 8, highlighting the government's overall subsidy/profit under the current $£ 3,200$ fee cap and with an example $£ 5,000$ average fee level, at three different example real interest rates.

Table 2. Average subsidy by fee level and interest rate

\begin{tabular}{l|ccc}
\hline \hline & \multicolumn{3}{|c}{ Real interest rate } \\
& $0 \%$ & $2.2 \%$ & $3.5 \%$ \\
\hline$£ 3,200 \mathrm{fee}$ & $£ 4,800$ & $£ 2,100$ & $-£ 100$ \\
$£ 5,000 \mathrm{fee}$ & $£ 6,900$ & $£ 3,600$ & $£ 1,100$ \\
\hline \hline
\end{tabular}

The table shows that if the government simply wanted to reduce the exchequer cost of the student support system, and was not concerned about raising any more money for the university sector, then its best course of action would be to keep the fee cap as it is and raise the interest rate - for example, to $3.5 \%$. This example interest rate would result in a big saving compared with the current system and would result in a small overall profit of around $£ 100$ per student. Raising the average fee level to $£ 5,000$, even with a $3.5 \%$ interest rate, would save the taxpayer money compared with the $£ 4,800$ per student cost of the current system, but would still result in an overall net subsidy per student payable by the taxpayer of $£ 1,100$ per graduate.

Figure 9 illustrates the distributional implications of increasing fees, showing an example average fee level of $£ 5,000$. We show this under two different 
systems, one with a real interest rate on loans and one without. The chart highlights the fact that increasing fees would lead to a sharp increase in the government subsidy payable to the poorest graduates (particularly those in the lowest $10-15 \%$ of the graduate lifetime earnings distribution), even if a real interest rate were imposed. This is because the poorest graduates, who already benefit from debt write-off, would be fully protected from having to pay any more towards the cost of their university tuition if fees were to rise, and effectively the government would cover the full cost of the fee rise for these students.

Figure 9. Average subsidy for a $₫ 5,000$ fee, with and without a $2.2 \%$ interest rate

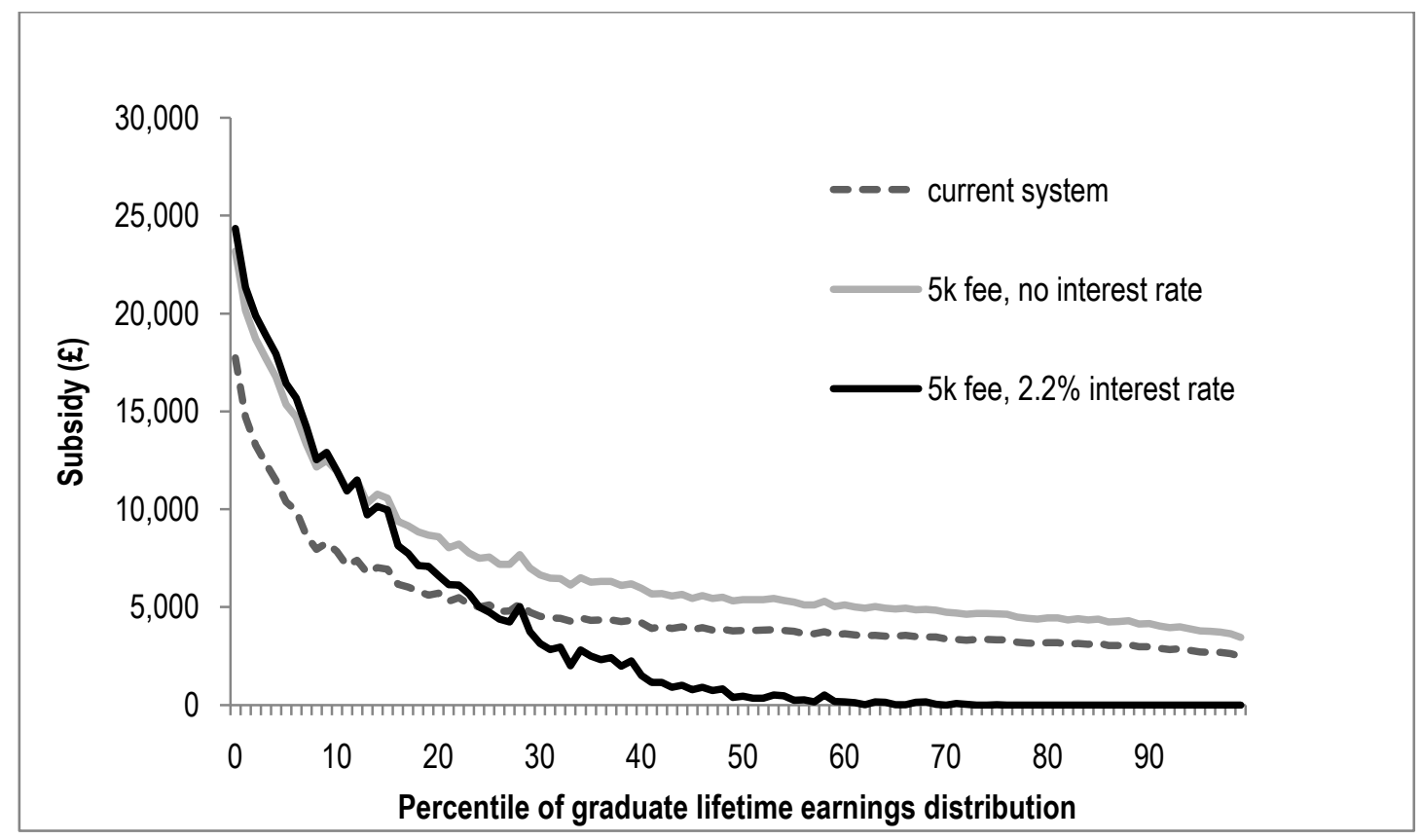

Looking at the implications for graduates who do not fall into the poorest groups, Figure 9 shows that if no interest rate were charged, the level of subsidy payable to graduates above the poorest $10-15 \%$ would also rise, due to the interest subsidy arising from the zero real interest rate on the additional fee. However, the charging of a real interest rate of $2.2 \%$ in conjunction with a rise in fees to an average of $£ 5,000$ would imply a reduction in the graduate subsidy for all but the poorest quarter of graduates, compared with the current system.

\subsection{The impact of behaviour change}

In Sections 4.1 and 4.2, we established that adding real interest rates to the value of graduate debt would result in a significant cost saving to the exchequer, while raising the fee cap would result in an increase in costs if an accompanying fee loan was provided for the full amount. 
However, this may not be the full story. In both cases, the cost of attending university would be significantly increased, and students and/or graduates may alter their behaviour in response.

For example, in a system with a positive real interest rate, a graduate's debt would increase each year by the amount of interest payable (less, obviously, any repayments made). It is therefore conceivable that, in the face of more costly debt, certain graduates might wish to make overpayments to their debt. Similarly, if the fee cap and accompanying loan were to be raised, graduates would face higher levels of debt and again may wish to make overpayments to reduce their loans faster.

Furthermore, increasing the cost of attending university through charging interest rates on loans or by raising the fee cap may also dissuade certain students from taking out loans. Maintenance loan take-up is currently $80 \%$, according to Student Loans Company statistics, ${ }^{11}$ while the take-up rate for fee loans is not publicly available. It is certainly the case that take-up could be reduced even further if the loans were made more expensive by charging real interest rates, though we do not know to what extent. The impact of such reduced take-up on the exchequer could be either positive or negative, depending on the future lifetime earnings paths of the students who decided not to take up the loans.

Finally, increasing the cost of attending university may also affect an individual's decision about whether to attend university at all. Recent IFS work suggests that an increase in up-front costs of higher education has a negative impact on participation ${ }^{12}$ (although no existing research, to our knowledge, tells us how responsive participation is to changes in deferred costs, assuming up-front costs remain unchanged).

Policymakers need to be aware of all these important factors in their HE finance decision-making.

\subsection{Altering other parameters of the student loan system: the loan repayment rate, debt write-off and the repayment threshold}

As we have seen, raising the fee cap will cost money and charging interest will save money. We have also seen that it is possible to combine the two in various ways to save the government money. However, there are other parameters that the government could adjust to save money, including the

\footnotetext{
${ }^{11}$ See Student Loans Company Statistical First Release 06/2009.

${ }^{12}$ L. Dearden, E. Fitzsimons and G. Wyness, 'The impact of higher education finance on university participation in the UK', Institute for Fiscal Studies, mimeo, January 2010.
} 
repayment rate (currently $9 \%$ of earnings above $£ 15,000$ ), the number of years after which debt is written off (currently 25 years) and/or the threshold at which people start repaying (currently $£ 15,000$ ). We consider each of these in turn.

\section{Changing the repayment rate}

With the current fee cap

The first parameter we consider is the repayment rate. Figure 10 shows the distributional impact of raising the repayment rate from its current level of $9 \%$ of earnings above $£ 15,000$, to an example repayment rate of $15 \%$ of earnings above $£ 15,000$.

Figure 10. Raising the repayment rate to $15 \%$ of earnings above $\mathbf{f 1 5 , 0 0 0}$

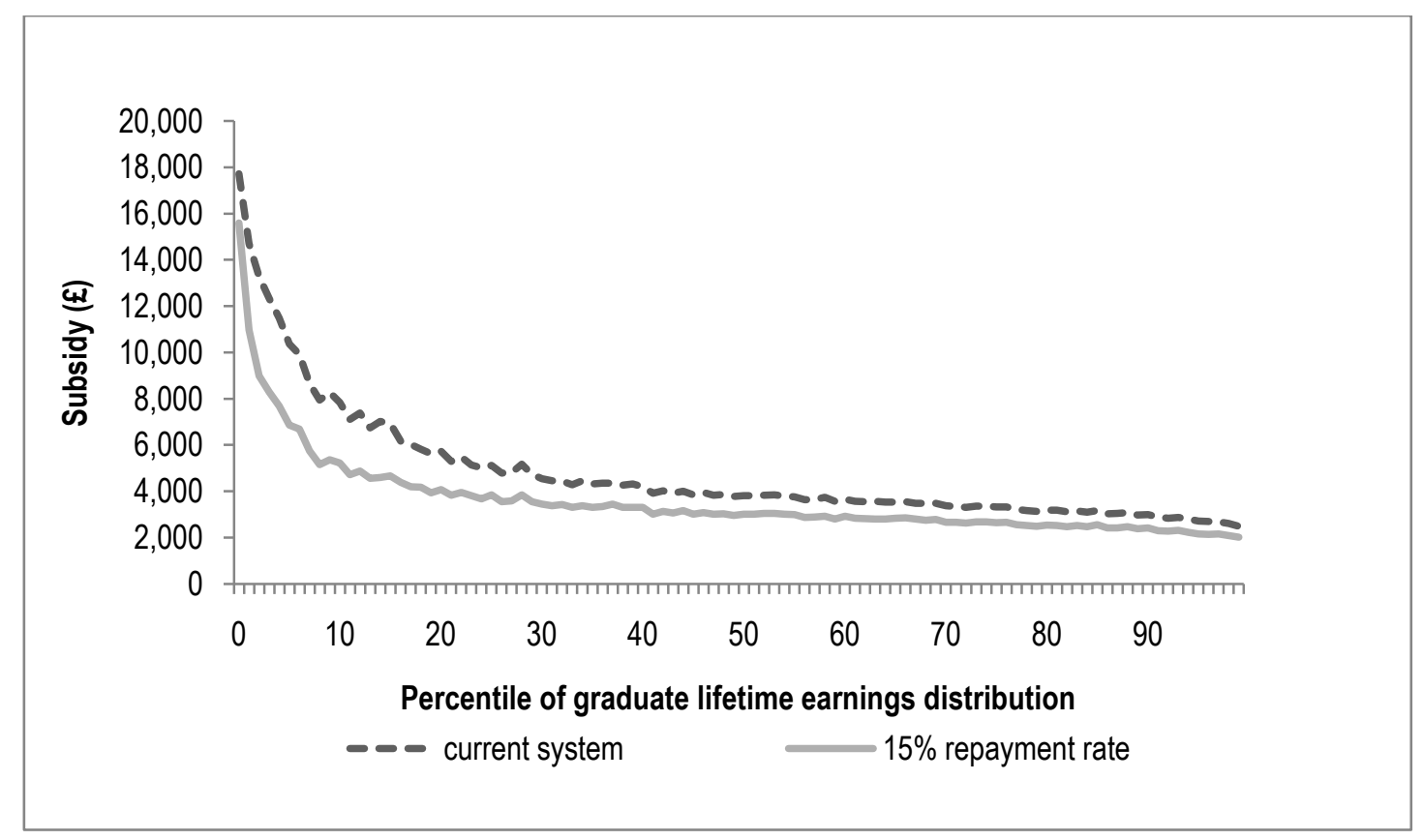

In this example, the government subsidy per student would fall from its current level of $£ 4,800$ to $£ 3,600$ - or the subsidy per $£ 1$ loaned would fall from $23 p$ to $17 p$. While this represents a significant saving of $£ 1,200$ per graduate, Figure 10 shows that this policy is quite regressive: the majority of savings would come from those graduates with earnings between the $5^{\text {th }}$ and $20^{\text {th }}$ percentiles.

This is because the impact of raising the repayment rate is simply to increase the speed at which repayments are made by all graduates earning above the $£ 15,000$ threshold. High-earning graduates, who would have repaid all their debt under the old system, will now do so more quickly. Thus, the only impact for these graduates is that they lose some of the subsidy they would normally 
receive from holding their loans for longer, at the government's expense. But those graduates who, under the old system, repaid only some of their loans before their debt was written off will now repay a larger proportion of their debt due to the increased rate of repayment.

Those graduates who always earn less than the $£ 15,000$ threshold, however, will be protected against the repayment rate increase.

Of course, the government may choose to set a lower repayment rate than $15 \%$, and may also combine this with a real interest rate.

In Figure 11, we show various combinations of repayment rates and interest rates for different levels of government subsidy at the current fee of $£ 3,200$ (2011 prices). This is similar to the analysis of 'fiscal indifference curves', constructed by Shephard (2010), ${ }^{13}$ although he used different debt parameters and earning assumptions.

Figure 11. Fiscal indifference curves for current fee level

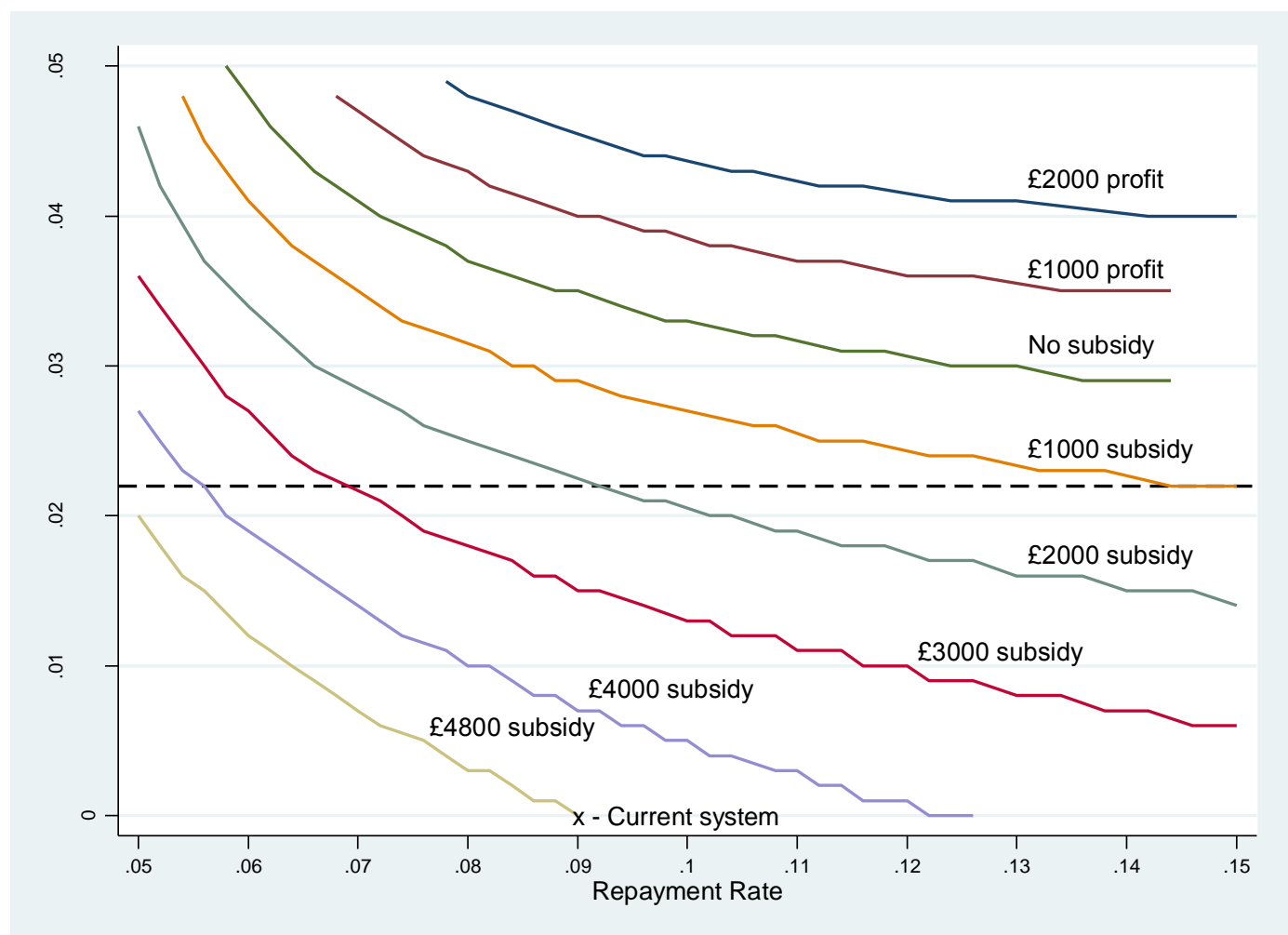

Note: Dashed line represents interest rate of 2.2\%, the government cost of borrowing.

\footnotetext{
${ }^{13} \mathrm{~N}$. Shephard, 'Submission to the review on "Higher Education Funding and Student Finance"', Oxford University, mimeo, 14 January 2010 (http://www.oxfordman.ox.ac.uk/ nshephard/submissionto140110.pdf).
} 
As can be seen from the $x$ marked on Figure 11, the current system involves an average taxpayer subsidy of $£ 4,800$ per student, a real interest rate of $0 \%$ and a repayment rate of $9 \%$.

Should the government wish to alter the repayment rate and/or the interest rate, a combination of these can be chosen which will either reduce costs or maintain the current level of subsidy.

For example, the current $£ 4,800$ subsidy could be achieved by reducing the repayment rate to $6 \%$ and counteracting this with an increase in interest rates to $1.2 \%$. Alternatively, the same subsidy could be achieved with an interest rate of $2 \%$ and a repayment rate of $5 \%$.

Alternatively, the government may wish to reduce the current subsidy. As we have previously discussed, the real interest rate required for the government to break even (i.e. pay out no overall subsidy) would be around $3.45 \%$ if the repayment rate remained unchanged at $9 \%$. However, the interest rate would need to be raised to only $3.2 \%$ if the repayment rate were also raised to $11 \%$, in order to break even. (This trade-off can be seen on the 'no subsidy' curve in Figure 11.)

Or, if the government wanted to make a $£ 2,000$ per graduate profit, it could do so by lowering repayment rates to $8 \%$, for example, and increasing interest rates to $4.8 \%$, or by raising repayment rates to $13 \%$ with an interest rate of $4.1 \%$.

Clearly, there are many different combinations of repayment rates and interest rates that can be combined to achieve the various targets. The distributional consequences of these different combinations of interest rates and repayment rates are very different. As Figure 10 illustrated, increasing the repayment rate is generally a regressive policy, which penalises lower-earning graduates more than higher-earning graduates, compared with the current system. In general, if the government wanted to reduce the taxpayer subsidy but maintain or improve the progressivity of the system, it could do so by imposing higher interest rates and lower repayment rates. (Of course, it could also improve the progressivity of the system by altering other parameters, such as the length of repayment in conjunction with an interest rate - as will be illustrated later in this section.)

The varying progressivity of various options is highlighted in Table 3, which shows all the combinations of interest rates and repayment rates that give an overall zero per-student subsidy. The table also shows the subsidy at the $10^{\text {th }}$ and $90^{\text {th }}$ centiles of the earnings distribution as well as the mean (which is zero by construction). We can see that the combinations that give the biggest taxpayer subsidy to the lowest-earning graduates and take the highest 'profit' 
from the highest earners are those that involve the highest interest rates and the lowest repayment rates. For a zero subsidy and of the combinations shown in Table 3, imposing a 5\% real interest rate and a 5.8\% repayment rate would give the biggest taxpayer subsidy to the lowest graduate earners.

While Table 3 is constructed on the assumption that graduates do not change their repayment behaviour in response to different systems, it also highlights the fact that the higher the interest rate charged, the more likely it is that high-earning graduates would increase their repayment rate in order to reduce the 'profit' that the taxpayer will make from them.

Table 3. Combinations of repayment rates and interest rates for zero government subsidy (at current fee levels)

\begin{tabular}{ccc|cc}
\hline \hline $\begin{array}{c}\text { Subsidy at } 10^{\text {th }} \\
\text { centile } \\
\text { of lifetime }\end{array}$ & $\begin{array}{c}\text { Mean } \\
\text { subsidy }\end{array}$ & $\begin{array}{c}\text { Subsidy at } 90^{\text {th }} \\
\text { centile } \\
\text { of lifetime } \\
\text { distribution }\end{array}$ & $\begin{array}{c}\text { Interest rate } \\
(\%)\end{array}$ & $\begin{array}{c}\text { Repayment rate } \\
(\%)\end{array}$ \\
\hline 15,200 & 0 & $-10,200$ & 5.0 & 5.8 \\
14,900 & 0 & $-9,400$ & 4.8 & 6.0 \\
14,500 & 0 & $-8,500$ & 4.6 & 6.2 \\
13,800 & 0 & $-7,300$ & 4.3 & 6.6 \\
13,500 & 0 & $-6,900$ & 4.2 & 6.8 \\
13,200 & 0 & $-6,400$ & 4.1 & 7.0 \\
12,900 & 0 & $-6,000$ & 4.0 & 7.2 \\
12,600 & 0 & $-5,600$ & 3.9 & 7.4 \\
12,000 & 0 & $-5,200$ & 3.8 & 7.8 \\
11,700 & 0 & $-4,800$ & 3.7 & 8.0 \\
11,100 & 0 & $-4,400$ & 3.6 & 8.4 \\
10,500 & 0 & $-4,000$ & 3.5 & 8.8 \\
10,200 & 0 & $-4,000$ & 3.5 & 9.0 \\
9,900 & 0 & $-3,700$ & 3.4 & 9.2 \\
9,600 & 0 & $-3,700$ & 3.4 & 9.4 \\
9,100 & 0 & $-3,300$ & 3.3 & 9.8 \\
8,800 & 0 & $-3,300$ & 3.3 & 10.0 \\
7,900 & 0 & $-2,900$ & 3.2 & 10.6 \\
7,700 & 0 & $-2,900$ & 3.2 & 10.8 \\
6,800 & 0 & $-2,600$ & 3.1 & 11.4 \\
6,500 & 0 & $-2,500$ & 3.1 & 11.6 \\
6,300 & 0 & $-2,500$ & 3.1 & 11.8 \\
5,400 & 0 & $-2,200$ & 3.0 & 12.4 \\
\hline \hline
\end{tabular}


With a $£ 5,000$ average fee

In the Appendix, we carry out the same exercise but with an average fee of $f 5,000$. As we showed in Section 4.2, under the current funding arrangements this involves a subsidy of $f 6,900$, as putting up fees with no other changes (other than the extension of fee loans to cover the increase) increases exchequer costs. Since increasing the average fee raises government costs (as described in Section 4.2), it is always necessary to have higher interest rates and/or repayment rates to neutralise the cost to the exchequer.

Also in the Appendix, we show the varying progressivity of combinations of interest rates and repayment rates with a $£ 5,000$ fee that lead to a zero perstudent subsidy (as in Table 3 for current fee levels) and those that lead to a $£ 2,000$ subsidy.

\section{Extending the debt write-off period}

Another option for reducing taxpayer costs and increasing graduate contributions is to extend the debt write-off period - for example, from 25 to 30 years, as is illustrated in Figure 12.

Figure 12. Extending the write-off period to 30 years

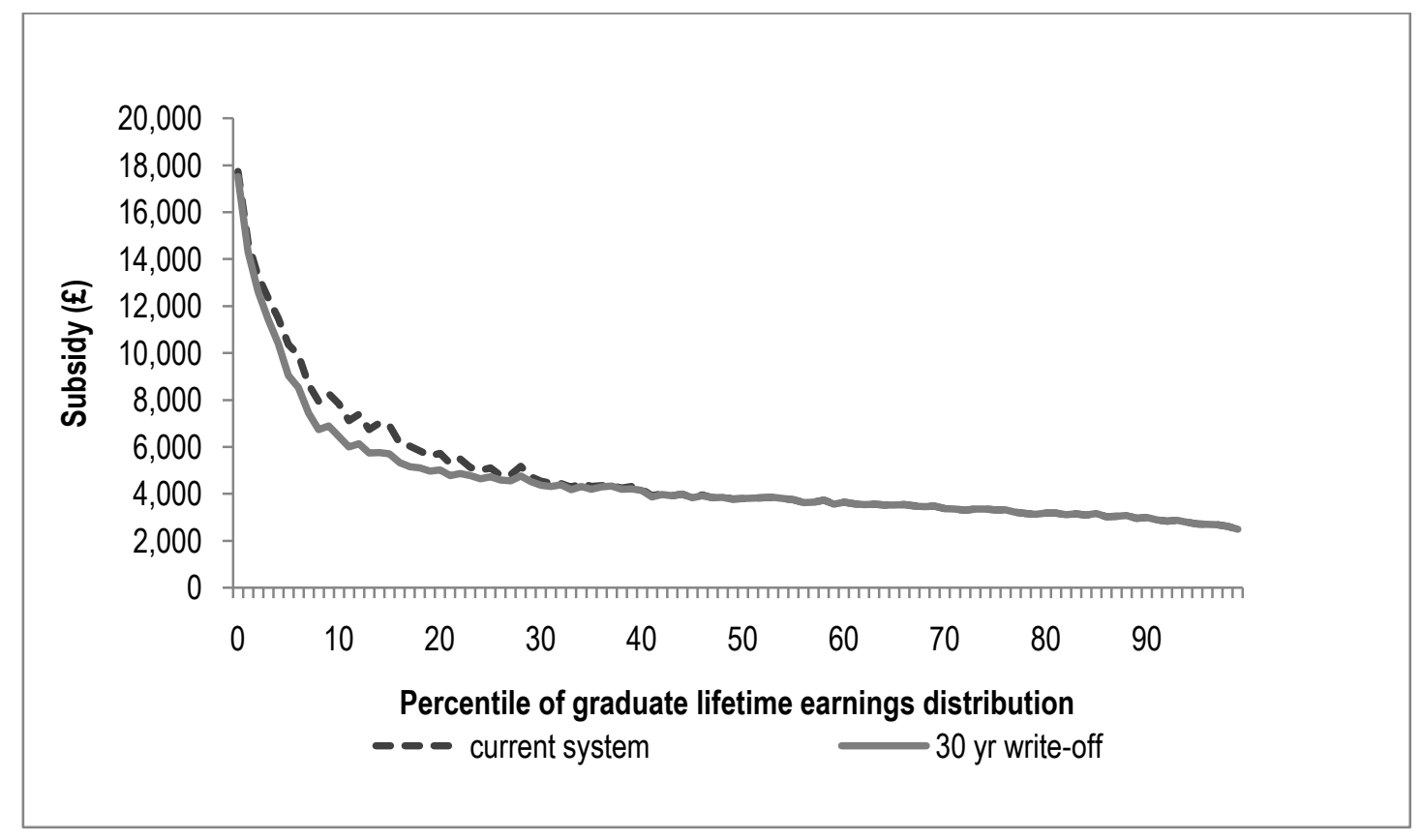

Extending the debt write-off to 30 years would reduce the cost of the current system by a small amount, from $£ 4,800$ to $£ 4,500$ per student, but as Figure 12 shows, this is a somewhat regressive policy: many of the gains from this type of reform are from relatively poor graduates who would have previously had their debt written off after 25 years and who now have to pay for up to a 
further 5 years. Better-off graduates who pay their debt off within 25 years are not affected by extending the debt write-off period - nor are those who earn below the threshold throughout their working lives, and therefore make no payments regardless of the debt write-off length.

Again, extending the write-off could be done in combination with changes in interest rates and repayment rates; various combinations are shown in the Appendix. Extending the period of debt write-off allows slight reductions in interest rates or repayment rates for the same level of subsidy - but, as above, this is likely to hit lower earners the most.

\section{Extending the repayment period}

A somewhat similar scenario to increasing the debt write-off period is one that involves extending the repayment period for a set number of years after a graduate has repaid his/her loan, ${ }^{14}$ under a system of real interest rates.

We illustrate this scenario by extending each graduate's loan length by two years after their last repayment and adding a $2.2 \%$ real interest rate. However, the other parameters of the system remain unchanged -25 -year debt write-off, $£ 15,000$ repayment threshold and $9 \%$ repayment rate.

The first panel of Figure 13 shows the system for men and women combined and also shows the current system with the addition of a $2.2 \%$ real interest rate. With the two-year extension, the exchequer gains $11 \mathrm{p}$ per $f 1$ loaned (compared with a subsidy of $10 p$ per $f 1$ loaned under a system with a $2.2 \%$ interest rate). Therefore this system is profitable.

But as Figure 13 also shows, this is quite a progressive scenario: the government only profits from graduates with earnings above the $25^{\text {th }}$ percentile. Those earning less than the $f 15,000$ threshold their whole lives will not make any additional payments under this new system; nor will those who do earn above the threshold, but reach the 25 -year write-off period without fully repaying their debt. Those with earnings above the $£ 15,000$ threshold who manage to repay their debt within 25 years will make up to an additional two years of repayments (at $9 \%$ of earnings over $f 15,000$ ). The additional repayments will average $£ 4,600$ per graduate making extra repayments.

\footnotetext{
${ }^{14}$ See N. Barr and A. Johnston, 'Interest subsidies on student loans: a better class of drain', Centre for the Economics of Education, Discussion Paper 114, March 2010.
} 
Figure 13. Extending the repayment period by two years
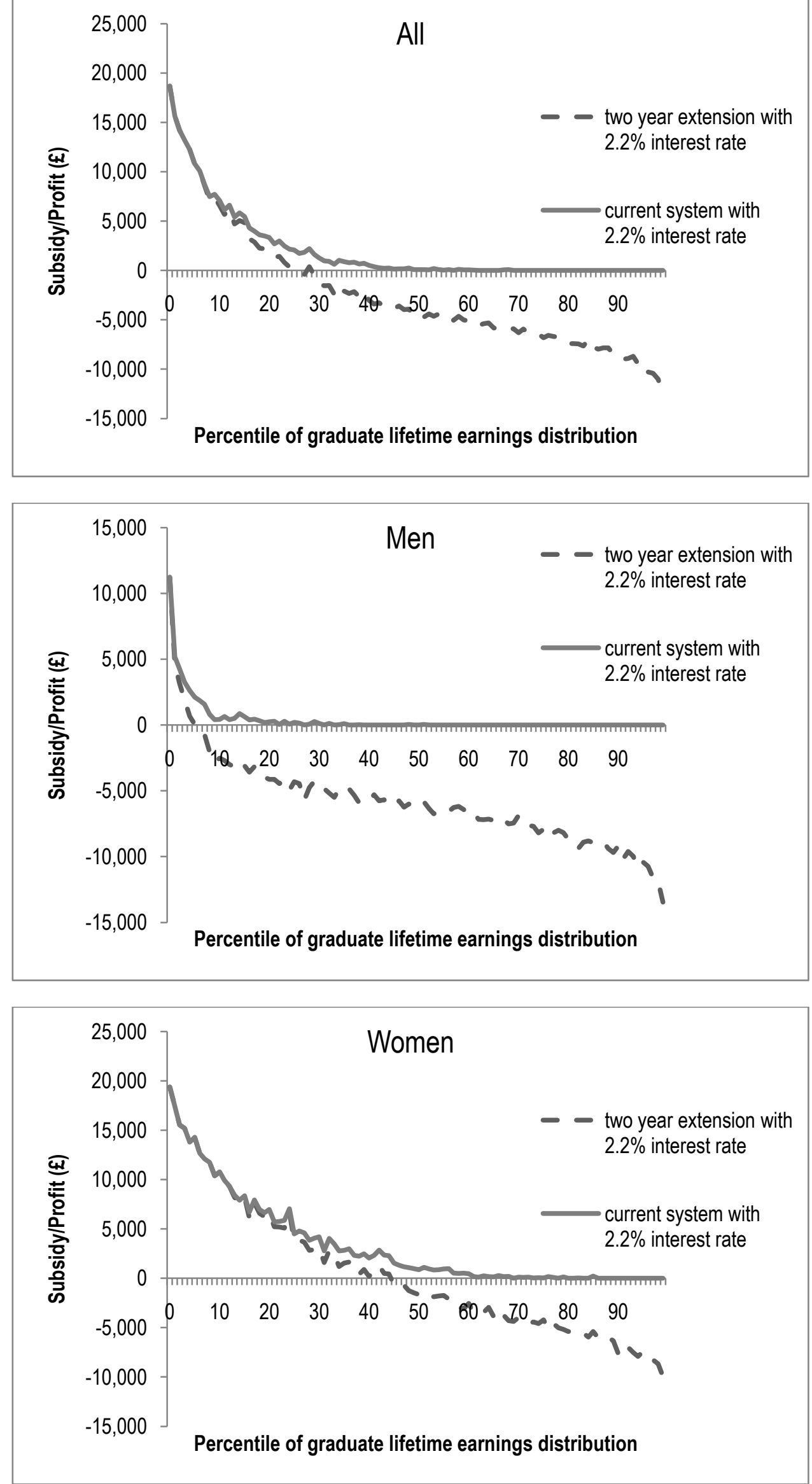
Looking separately at men and women, it can be seen that the majority of profit made by the government from this system comes from male graduates: those from around the $5^{\text {th }}$ percentile onwards repay more than their initial debt, and the resulting overall profit for the exchequer is $28 p$ per $f 1$ loaned. In contrast, only women with earnings at the $45^{\text {th }}$ percentile onwards generate a profit for the exchequer, so the government continues to subsidise female graduates to the tune of $2 p$ per $f 1$ loaned.

\section{Changing the repayment threshold}

Finally, the last parameter that can be changed is the repayment threshold, which currently stands at $£ 15,000$ (in nominal terms) and from 2011 will be uprated with inflation. Reducing the threshold raises money for the exchequer but the savings are made disproportionately from the lowest graduate earners. This is because the pool of graduates repaying their loans each year is increased and now includes some very low-earning graduates (those who earn salaries between the new threshold and $£ 15,000$ ).

\subsection{Offering students an up-front discount}

So far, this report has concentrated on the impact of changing existing aspects of the student loans system. However, the government may also consider adding new features to the system. One example of this is offering borrowers a discount if they choose to repay part or all of their loan early.

This policy is a current feature of the Australian HE loan system ${ }^{15}$ and has also been floated by the UK Conservative Party. ${ }^{16}$

\footnotetext{
${ }^{15}$ In the Australian system, students can make additional voluntary payments on their outstanding loan, and this will reduce their loan by an additional $10 \%$ of the extra payment (as long as this additional payment is over $\$ 500$ or fully repays their loan if less than $\$ 500$ outstanding). For example, if they pay an additional $\$ 1,000$ off their loan, they will reduce their outstanding loan by $\$ 1,100$. In Australia, students who take out a fee loan incur a loan fee of $20 \%$ (in effect, this implies an approximate $20 \%$ discount for paying up front). This is planned to increase to $25 \%$ from 1 July 2010 - see http://www.goingtouni.gov.au/NR/rdonlyres/76263DB4-71C5-478D-A448DAD447B60269/0/FEEHELP2010booklet Nov09.pdf for more details. Outstanding loans are only uprated by inflation.

${ }^{16}$ The Conservative Party has suggested a $10 \%$ discount for existing loanholders only, for an initial period of three years. Under this scheme, graduates would be given a $10 \%$ discount for early repayments over $£ 500$ and for up-front repayment of their loans. (See http://www.davidwilletts.co.uk/2009/10/05/conservatives-will-provide-an-extra-10000university-places-next-year/.) As this report and our data are based on new-entry students, we are unable to model this policy option specifically.
} 
In order for a system such as this to be profitable for the exchequer, however, graduates would have to repay more than under a system without the discount.

But if only those graduates who stand to benefit from the discount took advantage of it, the government would make a loss (clearly this must be the case, since any gain to graduates is a loss to the exchequer). While this policy would then free up money in the short term by bringing forward graduate repayment streams that otherwise would occur a long time in the future, it would do so at an overall long-term cost to the public finances.

If the policy is to be genuinely profitable, it relies on graduates voluntarily giving up some of the subsidies they are entitled to, for no financial gain (indeed, for a loss).

Evidence from Australia ${ }^{17}$ suggests that many graduates, and parents on their behalf, are indeed prepared to do this. However, the policy's profitability relies on students not choosing the best long-term option for them (which depends on future lifetime earnings) and/or their lack of knowledge about the HE system.

\section{The balance between public and private contributions}

While this report has primarily concentrated on the possible savings for or costs to the exchequer, and the distributional effects for graduates of various policy options, it is illuminating to consider how each of these groups as a whole, as well as taxpayers and universities, is affected by the reforms.

In this section, we illustrate this by means of circular flows of payments. This shows the net payments to and receipts from the different participants within the HE system: universities, students, graduates and taxpayers. Accounting for both where payments come from and where they go to results in a zero-sum. Comparing such zero-sums across different systems gives us a clear indication of the net contributors and receivers from each of the scenarios.

Tables 4-6 set out our calculations of the net balance of payments (negative in the tables) and receipts (positive in the tables) between different groups in the current system of higher education in funding in England, and under our two main scenarios of adding a real interest rate of $2.2 \%$ and of increasing the average fee to $£ 5,000$, and also a combination of the two.

\footnotetext{
${ }^{17}$ See, for example, http://www.independent.co.uk/news/education/higher/should-wefollow-the-kiwis-and-offer-discounts-for-graduates-who-pay-off-their-student-loans-early1932332.html.
} 
In each case, as well as considering the loans system, we consider maintenance grants paid to students and the full value of the grants paid from central government to universities for undergraduate teaching, which are channelled through HEFCE. The figures are constructed as follows:

- taxpayers - pay out HEFCE money, ${ }^{18}$ maintenance grants, and fee and maintenance loan subsidies;

- students - receive maintenance grants and loans;

- graduates - pay fee and maintenance loans (less loan subsidies);

- universities - receive HEFCE and tuition fee money. ${ }^{19}$

\section{Adding a real interest rate of $2.2 \%$}

Looking first at Table 4, the first column shows the current system. Here, universities received about $f 7,800$ per student funding for teaching, coming mainly from taxpayers (via direct payments to universities in the form of the recurrent teaching grant made to HEFCE each year - amounting to $£ 4,600$ per student per year), and also from graduates (via deferred fees). Graduates make a net contribution, from maintenance and fee loan repayments (less the taxpayer subsidy, or unpaid part of the loan). Students receive $f 5,000$ each on average, from maintenance grants and loans.

Table 4. Circular flows of payments, current system and system with $2.2 \%$ real interest rate ( $f$ per year of study)

\begin{tabular}{l|ccc}
\hline \hline & $\begin{array}{c}\text { CURRENT } \\
\text { 2009-10 system }\end{array}$ & $\begin{array}{c}\text { NEW } \\
\text { 2.2\% interest rate } \\
\text { system }\end{array}$ & $\begin{array}{c}\text { New system } \\
\text { compared with } \\
\text { current system }\end{array}$ \\
\hline Taxpayers & $-7,400$ & $-6,500$ & +900 \\
Students & $+5,000$ & $+5,000$ & 0 \\
Graduates & $-5,400$ & $-6,300$ & -900 \\
Universities & $+7,800$ & $+7,800$ & 0 \\
Sums of gains and losses & $£ 0$ & $f 0$ & $£ 0$ \\
\hline \hline
\end{tabular}

The second column of the table shows that taxpayers are made better off under a $2.2 \%$ real interest rate, with the average taxpayer subsidy falling to $£ 6,500$. Graduates, meanwhile, are worse off since they now have to pay interest on their loans.

The final column of Table 4 allows us to understand the net impact of all these changes: the taxpayer saves $f 900$ per student per year (from reducing the loan subsidy), while graduates each lose $£ 900$ per year (from increased loan

\footnotetext{
${ }^{18}$ HEFCE teaching grant (source: HEFCE grant letter 2010, http://www.hefce.ac.uk/news/HEFCE/2009/grant1011/letter.htm).
}

${ }^{19}$ Note that bursaries are not included in these calculations. 
repayments). This scenario does not affect student or university costs / income since they gain or lose nothing from the rise in interest rates.

\section{Increasing the average fee to $£ 5,000$}

Table 5 considers the circular flow of payments arising from increasing the average fee level to $£ 5,000$.

Table 5. Circular flows of payments, current system and system with $£ 5,000$ average tuition fee ( $f$ per year of study)

\begin{tabular}{l|ccc}
\hline \hline & $\begin{array}{c}\text { CURRENT } \\
\text { 2009-10 system }\end{array}$ & $\begin{array}{c}\text { NEW } \\
\text { f5k average fee } \\
\text { system }\end{array}$ & $\begin{array}{c}\text { New system } \\
\text { compared with } \\
\text { current system }\end{array}$ \\
\hline Taxpayers & $-7,400$ & $-8,100$ & -700 \\
Students & $+5,000$ & $+5,000$ & 0 \\
Graduates & $-5,400$ & $-6,500$ & $-1,100$ \\
Universities & $+7,800$ & $+9,600$ & $+1,800$ \\
Sums of gains and losses & $£ 0$ & $£ 0$ & $£ 0$ \\
\hline \hline
\end{tabular}

In this case, universities gain $£ 1,800$ per student, due to the increase in tuition fee payments of $£ 1,800$ per year (this represents the increase from the current fee level of $£ 3,200$ at 2011 prices, to $£ 5,000$ ). Students are unaffected by the reform since we have assumed that the fee increase will be fully covered by a loan. Graduates, meanwhile, increase their contribution by $£ 1,100$ per year of study $-£ 3,300$ in total, representing the increase in debt repayments. Taxpayers also make an increased contribution of $£ 700$ per person per year of study in the form of the increase in graduate subsidy arising from the fee increase.

\section{Adding a real interest rate of $2.2 \%$ and increasing the average fee to $£ 5,000$}

Finally, in Table 6, we consider the flow of payments arising from charging a $2.2 \%$ interest rate and increasing the average fee to $£ 5,000$.

Table 6. Circular flows of payments, current system and system with $2.2 \%$ real interest rate and $£ 5,000$ average tuition fee ( $f$ per year of study)

\begin{tabular}{l|ccc}
\hline \hline & $\begin{array}{c}\text { CURRENT } \\
\text { 2009-10 system }\end{array}$ & $\begin{array}{c}\text { NEW } \\
\mathbf{2 . 2 \%} \text { interest rate + } \\
\text { f5k fee system }\end{array}$ & $\begin{array}{c}\text { New system } \\
\text { compared with } \\
\text { current system }\end{array}$ \\
\hline Taxpayers & $-7,400$ & $-7,000$ & +400 \\
Students & $+5,000$ & $+5,000$ & 0 \\
Graduates & $-5,400$ & $-7,600$ & $-2,200$ \\
Universities & $+7,800$ & $+9,600$ & $+1,800$ \\
Sums of gains and losses & $f 0$ & $f 0$ & $f 0$ \\
\hline \hline
\end{tabular}

In this instance, again universities gain $f 1,800$ from the increase in fee revenue. But now the taxpayer also makes a small net gain, of $£ 400$ per 
student per year (since the subsidy falls by $£ 1,200$ from $£ 4,800$ to $£ 3,600$ over three years, or $£ 400$ per year - see Table 2 ). The biggest losers in this scenario are graduates, who must increase their contribution by $£ 2,200$ per year, in the form of increased loan repayments.

\section{Conclusions}

The options for funding higher education are complex. There are many choices available to the government, depending on what its key objectives are. In this paper, we have attempted to highlight some of the trade-offs that are involved in a wide range of possible reforms.

Our analysis shows, in summary, that:

- Under our simulations, the current maintenance and fee loan system results in an average taxpayer subsidy of $23 p$ for every $£ 1$ loaned to a student. Given an average debt level for a graduate of a three-year undergraduate degree of $£ 20,900$, this amounts to a taxpayer subsidy of $£ 4,800$ per graduate who takes out a loan.

- Charging an interest rate on loans saves the taxpayer money - for example, a $2.2 \%$ interest rate reduces the taxpayer subsidy to $10 p$ for every $f 1$ loaned, and if the government charged an interest rate of $3.45 \%$ there would be no subsidy (assuming no behavioural change).

- Charging a positive real interest rate generates slightly more savings from male and female graduates in the middle of the lifetime earnings distribution than from those at either the bottom or the top. This is because these graduates do not benefit from the debt write-off subsidy, but benefit most from the interest subsidy.

- Increasing the fee cap costs the taxpayer money (assuming that fee loans would be extended to cover the increased fees), but this cost can be reduced by increasing interest rates in conjunction with increasing fees. Under a $£ 5,000$ average fee, for example, if a $1.5 \%$ real interest rate were charged, then the taxpayer subsidy would not need to increase beyond the $£ 4,800$ subsidy implied by the current system. A further consequence of raising fees is that it may result in a decrease in university participation.

- Other parameters of the loan system can be adjusted to achieve the same subsidy as the current system or a lower one - changes can be made, for example, to the repayment rate, the number of years after which debt is written off or the threshold at which people start repaying. However, it is vital to consider the distributional consequences for different types of graduates. For instance, increasing the debt write-off period would result 
in all exchequer gains being made from relatively poor graduates; reducing the repayment threshold would result in savings for the government, but is also regressive.

- Different interest rates and repayment rates can also be combined to produce subsidies as desired - but also, crucially, to improve the progressivity of the system. For example, a zero subsidy could be achieved by imposing an interest rate of $3.45 \%$ if the repayment rate remained unchanged at $9 \%$. However, imposing a $5 \%$ real interest rate and a $5.8 \%$ repayment rate would still achieve a zero subsidy but would give the biggest taxpayer subsidy to the lowest graduate earners. Other progressive options include lengthening the repayment period for a further two years after graduates have paid off their loans.

- Alternatively, the government could introduce new features to the system, such as up-front discounts. However, in order to make money from such discounts, it needs to induce graduates who would lose out from taking the discount to actually take it up.

- Finally, increasing the cost of attending university may result in behavioural changes by both students and graduates, which may be difficult to predict.

\section{Appendix}

\section{Alternative earnings growth scenarios}

The results in this report are mainly based on a central scenario of earnings level and growth, but we also have results under an optimistic and a pessimistic scenario.

The assumptions made under each scenario are as follows:

- Central scenario (as used in the main body of this report):

- $4.5 \%$ fall in earnings over $2007-10$ relative to trend, which implies growth of $1.8 \%$ per year between 2008 and 2014

- long-term average earnings growth at 2\% per year from 2014

- Optimistic scenario:

- $4.5 \%$ fall in earnings over $2007-10$ relative to trend, which implies growth of $1.8 \%$ per year between 2008 and 2014

- long-term average earnings growth at 2.25\% per year from 2014

- Pessimistic scenario:

- $10 \%$ fall in earnings over $2007-10$ relative to trend, which implies growth of $0.7 \%$ per year between 2008 and 2014

- long-term average earnings growth at 1.75\% per year from 2014 
These are based on the detailed macroeconomic forecasts contained in the IFS Green Budget 2010. ${ }^{20}$

Figures 14-16 illustrate the net present value of repayments, the subsidy as a percentage of the original loan, and the number of years taken to repay the loan under our alternative earnings growth scenarios.

Figure 14. Net present value of repayments per graduate, alternative earnings growth scenarios

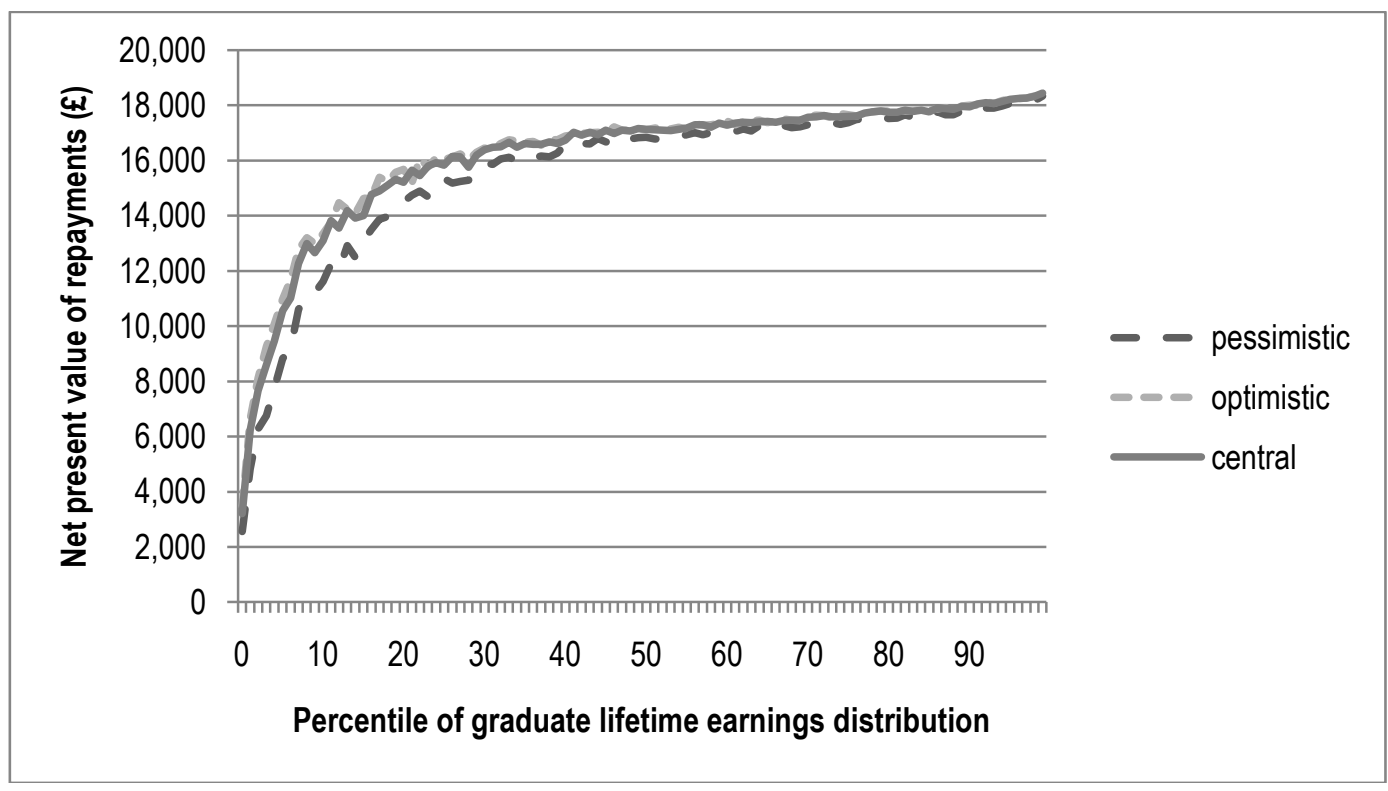

Figure 15. Subsidy as a percentage of loan, alternative earnings growth scenarios

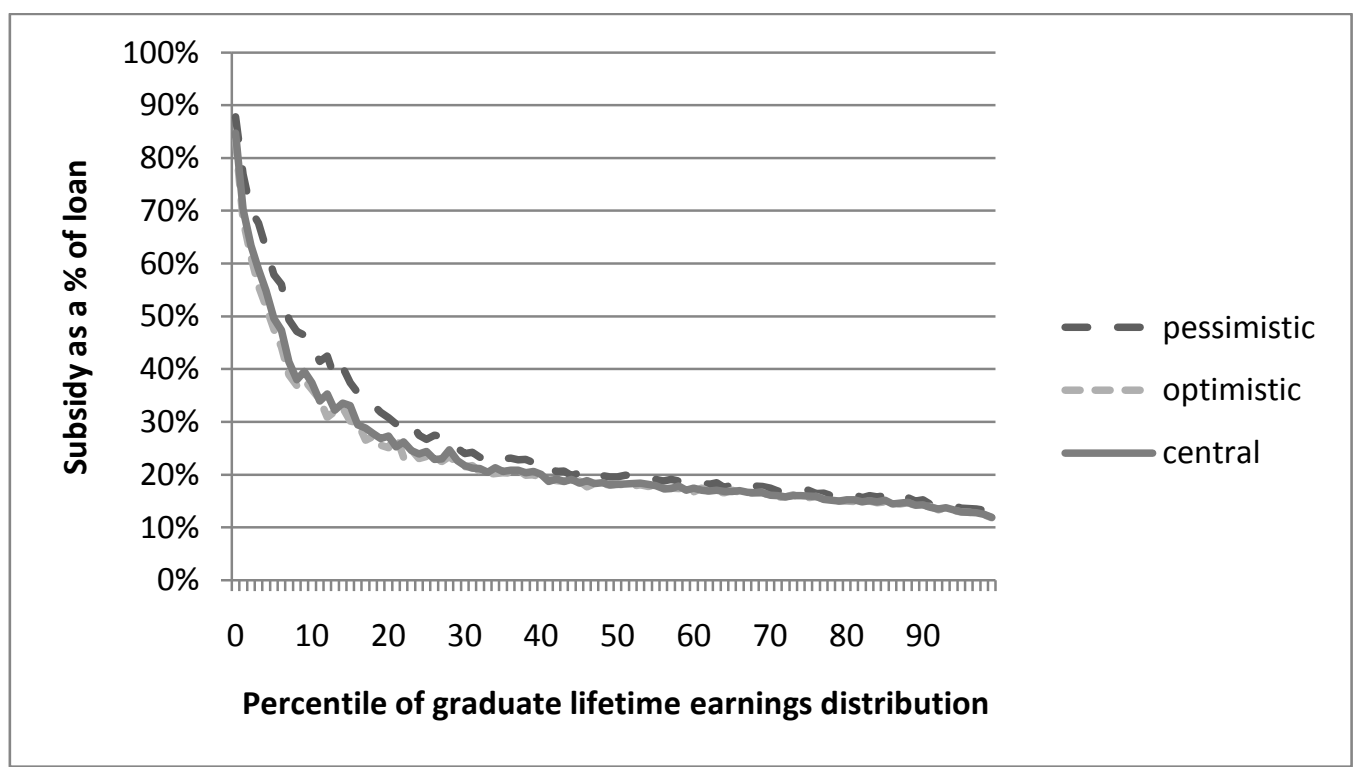

${ }^{20}$ See appendix A of R. Chote, C. Emmerson and J. Shaw (eds), The IFS Green Budget: February 2010, Commentary 112, Institute for Fiscal Studies, London, 2010 (http://www.ifs.org.uk/publications/4732). 
Figure 16. Years to repay loan, alternative earnings growth scenarios

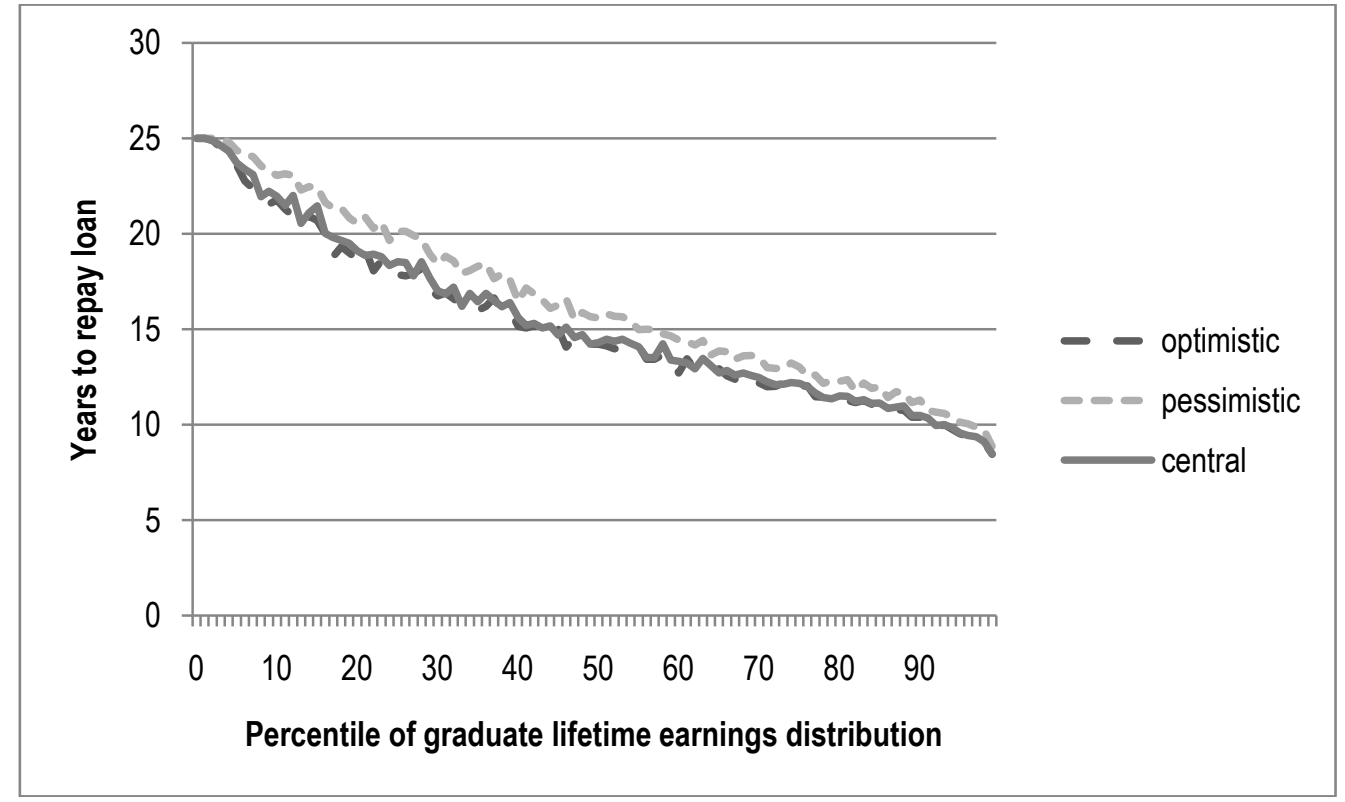

\section{Altering other parameters of the student loan system}

A $£ 5,000$ fee

Figure 17 shows the various combinations of interest rates and repayment rates for different levels of government subsidy with a $£ 5,000$ fee level. If the government wanted to keep the taxpayer subsidy at current levels (of $£ 4,800$ ), then it is clear from the chart that with a repayment rate of between $5 \%$ and $15 \%$, the government will need to introduce a real interest rate on loans (the $£ 4,800$ subsidy indifference curve never crosses the zero real interest rate level at repayment rates between $5 \%$ and $15 \%)$.

To reduce the government subsidy, other combinations will need to be found. For instance, if the government subsidy were reduced to $£ 2,000$ per student, then the current repayment rate of $9 \%$ would need an interest rate of $3.1 \%$. This would involve a subsidy of $£ 15,800$ to those in the bottom $10 \%$ of the lifetime earnings distribution and a $£ 3,500$ 'profit' taken from those in the top $10 \%$ of the lifetime earnings distribution. An interest rate of $2.2 \%$ and a repayment rate of $11.6 \%$ would involve no taxpayer subsidy for the top $10 \%$ of lifetime earners and an $£ 11,800$ subsidy for the lowest $10 \%$ of lifetime earners. 
Figure 17. Fiscal indifference curves for $₫ 5,000$ fee

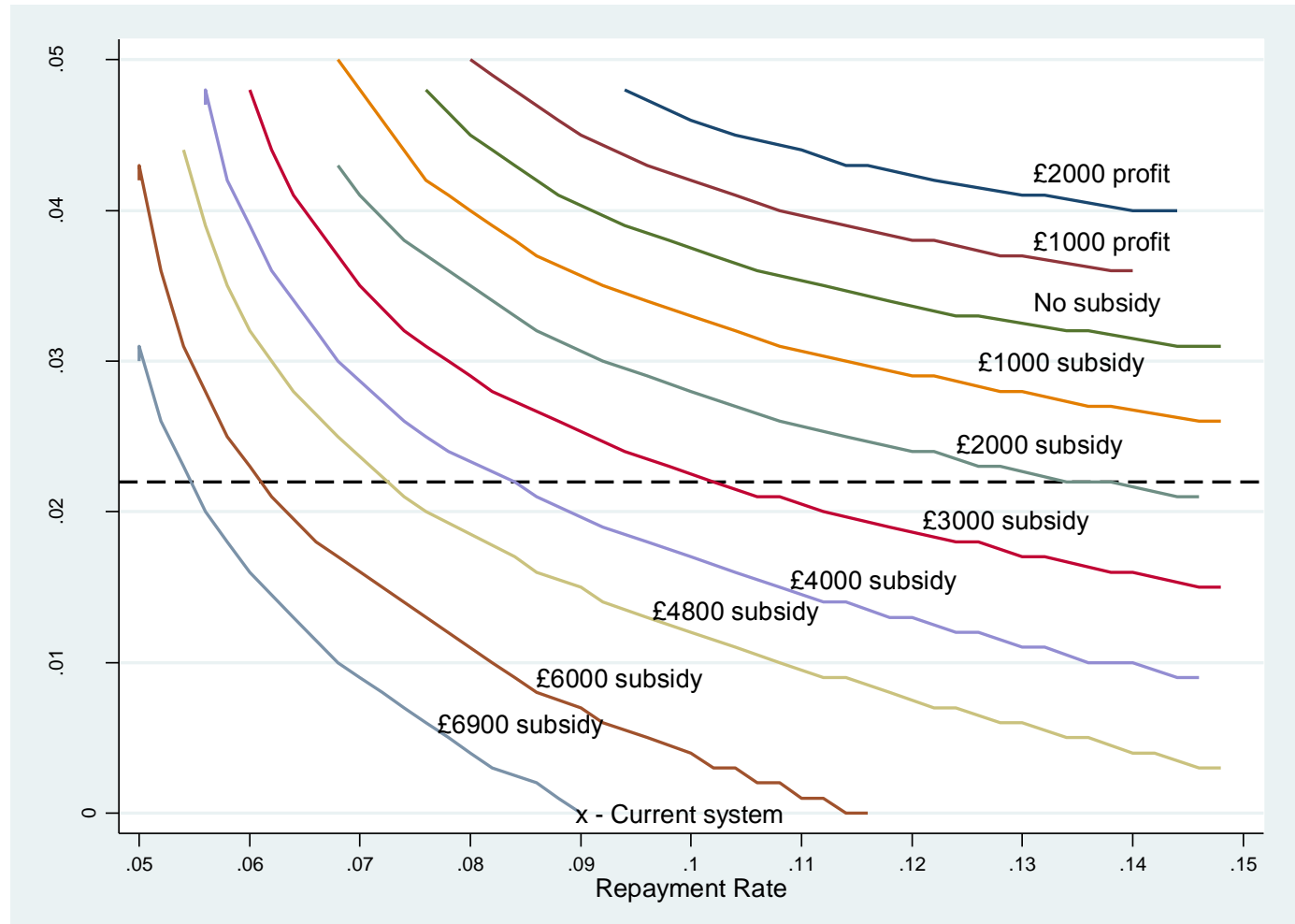

Notes: Dashed line represents interest rate of $2.2 \%$, the government cost of borrowing. 'Current system' refers to current interest and repayment rates.

The varying progressivity of various options of interest rates and repayment rates is illustrated in Tables 7 and 8, which show (in Table 7) various combinations of interest rates and repayment rates that give an overall zero per-student subsidy and (in Table 8) various combinations that give a $£ 2,000$ subsidy. Like Table 3 , these tables also show the subsidy at the $10^{\text {th }}$ and $90^{\text {th }}$ centiles of the earnings distribution as well as at the mean (which is zero in Table 7 and 2,000 in Table 8, by construction).

For example, in Table 7, the combination of interest rate and repayment rate that would provide a cost-neutral system and the biggest subsidy for low-earning graduates is an interest rate of $4.8 \%$ and a repayment rate of $7.6 \%$. Under the current repayment rate of $9 \%$, interest rates would have to be set around $4 \%$ to achieve a cost-neutral system. 
Table 7. Combinations of repayment rates and interest rates for zero government subsidy (with $f 5,000$ average fee)

\begin{tabular}{ccc|cc}
\hline $\begin{array}{c}\text { Subsidy at } 10^{\text {th }} \\
\text { centile } \\
\text { of lifetime }\end{array}$ & $\begin{array}{c}\text { Mean } \\
\text { subsidy }\end{array}$ & $\begin{array}{c}\text { Subsidy at } 90^{\text {th }} \\
\text { centile } \\
\text { of lifetime } \\
\text { earnings }\end{array}$ & $\begin{array}{c}\text { Interest rate } \\
(\%)\end{array}$ & $\begin{array}{c}\text { Repayment rate } \\
(\%)\end{array}$ \\
\hline 18 distribution & 0 & $-11,800$ & 4.8 & 7.6 \\
18,700 & 0 & $-10,800$ & 4.6 & 7.8 \\
18,300 & 0 & $-10,200$ & 4.5 & 8.0 \\
18,000 & 0 & $-9,700$ & 4.4 & 8.2 \\
17,700 & 0 & $-9,200$ & 4.3 & 8.4 \\
17,300 & 0 & $-8,600$ & 4.2 & 8.6 \\
17,000 & 0 & $-8,100$ & 4.1 & 8.8 \\
16,700 & 0 & $-7,100$ & 3.9 & 9.4 \\
15,800 & 0 & $-6,600$ & 3.8 & 9.8 \\
15,200 & 0 & $-6,100$ & 3.7 & 10.2 \\
14,600 & 0 & $-5,600$ & 3.6 & 10.6 \\
14,000 & 0 & $-5,100$ & 3.5 & 11.2 \\
13,100 & 0 & $-4,600$ & 3.4 & 11.8 \\
12,200 & 0 & $-4,100$ & 3.3 & 12.6 \\
11,100 & 0 & $-4,100$ & 3.3 & 12.4 \\
11,400 & 0 & $-3,700$ & 3.2 & 13.6 \\
9,700 & 0 & $-3,700$ & 3.2 & 13.4 \\
9,900 & 0 & $-3,200$ & 3.1 & 14.8 \\
8,000 & 0 & $-3,200$ & 3.1 & 14.6 \\
8,300 & 0 & $-3,200$ & 3.1 & 14.4 \\
8,500 & 0 & & & \\
\hline \hline
\end{tabular}


Table 8. Combinations of repayment rates and interest rates for $£ 2,000$ government subsidy (with $£ 5,000$ average fee)

\begin{tabular}{ccc|cc}
\hline $\begin{array}{c}\text { Subsidy at } 10^{\text {th }} \\
\text { centile } \\
\text { of lifetime }\end{array}$ & $\begin{array}{c}\text { Mean } \\
\text { subsidy }\end{array}$ & $\begin{array}{c}\text { Subsidy at } 90^{\text {th }} \\
\text { centile } \\
\text { of lifetime } \\
\text { earnings }\end{array}$ & $\begin{array}{c}\text { Interest rate } \\
(\%)\end{array}$ & $\begin{array}{c}\text { Repayment rate } \\
(\%)\end{array}$ \\
\hline distribution & distribution & & 6.8 \\
19,500 & 2,000 & $-9,200$ & 4.3 & 7.0 \\
19,100 & 2,000 & $-8,200$ & 4.1 & 7.4 \\
18,400 & 2,000 & $-6,800$ & 3.8 & 8.4 \\
16,800 & 2,000 & $-4,400$ & 3.3 & 8.6 \\
16,400 & 2,000 & $-4,000$ & 3.2 & 9.2 \\
15,500 & 2,000 & $-3,100$ & 3.0 & 9.6 \\
14,900 & 2,000 & $-2,600$ & 2.9 & 10.0 \\
14,300 & 2,000 & $-2,200$ & 2.8 & 10.4 \\
13,700 & 2,000 & $-1,800$ & 2.7 & 10.8 \\
13,100 & 2,000 & $-1,400$ & 2.6 & 11.4 \\
12,300 & 2,000 & $-1,100$ & 2.5 & 12.2 \\
11,100 & 2,000 & -700 & 2.4 & 12.0 \\
11,400 & 2,000 & -700 & 2.4 & 12.8 \\
10,300 & 2,000 & -300 & 2.3 & 12.6 \\
10,500 & 2,000 & -300 & 2.3 & 13.8 \\
8,900 & 2,000 & 0 & 2.2 & 13.6 \\
9,100 & 2,000 & 0 & 2.2 & 13.4 \\
9,400 & 2,000 & 0 & 2.2 & 14.6 \\
7,700 & 2,000 & 200 & 2.1 & \\
8,000 & 2,000 & 200 & 2.1 & \\
\hline
\end{tabular}

Extending the write-off period to 30 years

If the write-off period were extended to 30 years, the current $£ 4,800$ subsidy could be achieved by lowering the repayment rate to $8 \%$, or by reducing it even further and raising interest rates. Figure 18 also shows other, less costly, options. 
Figure 18. Fiscal indifference curves for 30-year write-off of outstanding debt

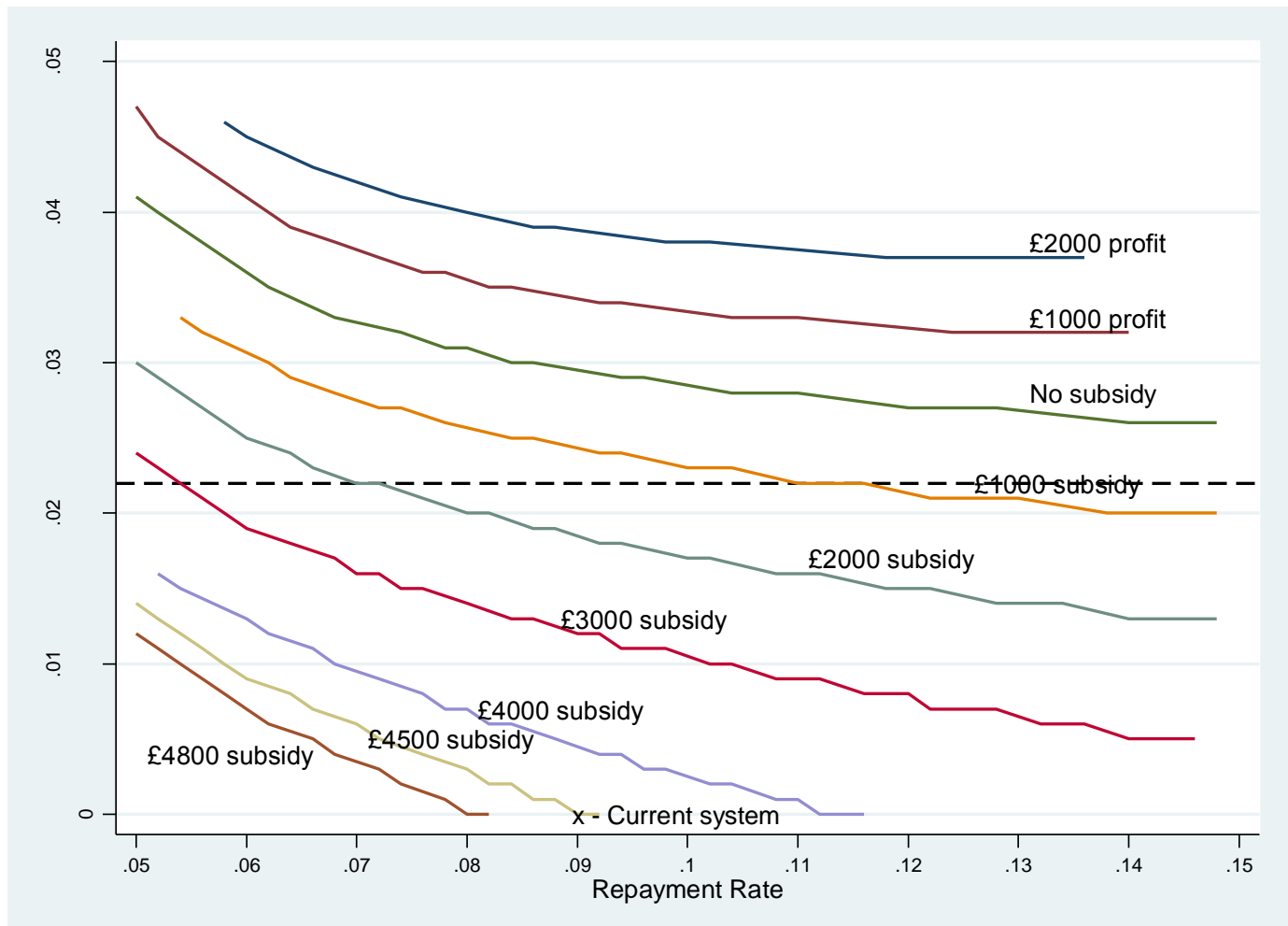

Notes: Dashed line represents interest rate of $2.2 \%$, the government cost of borrowing. 'Current system' refers to current interest and repayment rates.

\section{Technical appendix}

\section{Construction of simulated lifetime earnings profiles}

\section{Overview}

Our simulated lifetime earnings profiles are constructed as follows. We start by using the British Household Panel Survey (BHPS) to estimate a rich statistical model for the dynamics of log annual earnings. We then estimate three models of annual employment dynamics, also using the BHPS. These models jointly determine a dynamic process that determines the probability of exiting employment, the probability of re-entering employment after a spell of non-employment and the annual earnings of re-employed individuals. Next we simulate a large number of individual paths from these estimated earnings and employment models. Finally, we adjust the simulations to be consistent with the age-specific cross-sectional distributions of earnings for employed individuals in the Labour Force Survey (LFS). To do this, we transform the simulated cross-sectional distributions of non-zero earnings so that each percentile of the simulated distribution coincides with the corresponding percentile from the LFS at the relevant age.

The final simulations can thus be thought of as a hybrid model that features earnings and employment dynamics from the BHPS, but with cross-sectional earnings distributions (and levels) that are consistent with the LFS. 


\section{Data issues}

BHPS: sample selection

We define each individual's education level as the highest attained level by age 22 . In addition, we include as graduates any individuals who attained their degree at age 23. We include all graduates in the sample from ages 22 to 60 . Our data are from the first 16 waves of the BHPS, covering the years 1991 to 2006.

BHPS: definition of earnings

Annual earnings are defined as annual labour income in the reference year from September in the year prior to the interview until September in the year in which interviewing begins. All earnings are expressed in 2011 pounds with uprating according to the retail price index (all items). ${ }^{21}$ We treat observations with annual earnings below $£ 1,000$ as zero annual earnings.

\section{LFS: sample selection}

We define each individual's education level as the highest attained level by age 22 . We include all graduates in the sample from ages 22 to 60 . Our data are quarterly, from 1993Q1 to 2009 Q2.

\section{LFS: definition of earnings}

Annual earnings are defined as gross weekly pay in main job, multiplied by 52 . All earnings are expressed in 2011 pounds with uprating according to the retail price index (all items). ${ }^{22}$ We treat observations with annual earnings below $£ 1,000$ as zero annual earnings.

\section{Model for log annual earnings}

Let $Y_{\text {iat }}$ be annual earnings for individual $i$ at age $a$ in year $t$. For individuals with nonzero annual earnings, let $y_{i a t}=\log Y_{\text {iat }}$ be log annual earnings. We assume the following statistical process for $y_{\text {iat }}$ :

$$
\begin{aligned}
y_{i a t} & =\beta X_{i a t}+\hat{y}_{i a t} \\
\hat{y}_{i a t} & =\alpha_{i}+\gamma_{i} a+u_{i a t}+z_{i a t} \\
u_{i a t} & =\varepsilon_{i a t}+\theta \varepsilon_{i, a-1, t-1} \\
z_{i a t} & =\rho z_{i, a-1, t-1}+\eta_{i a t} \\
z_{i 0 t} & =0 \\
\varepsilon_{i 0 t} & =0
\end{aligned}
$$

\footnotetext{
${ }^{21}$ See http://www.statistics.gov.uk/downloads/theme_economy/FinStats_Dec09.pdf, table 7.2A, CHAW.

${ }^{22}$ See http://www.statistics.gov.uk/downloads/theme_economy/FinStats_Dec09.pdf, table 7.2A, CHAW.
} 
All shocks are assumed to follow normal distributions:

$$
\begin{aligned}
& \alpha_{i} \sim N \quad 0, \sigma_{\alpha, a}^{2} \\
& \gamma_{i} \sim N \quad 0, \sigma_{\gamma, a}^{2} \\
& \eta_{i a t} \sim N \quad 0, \sigma_{\eta, a}^{2} \\
& \varepsilon_{i a t} \sim N \quad 0, \sigma_{\varepsilon, a}^{2}
\end{aligned}
$$

$X_{\text {iat }}$ is a vector of observable characteristics for individual $i$ that include a quartic polynomial in age, a full set of year dummies, and dummies for region and ethnicity. $\alpha_{i}$ is an individual-specific fixed effect and $\gamma_{i}$ is an individual-specific deterministic linear trend in age. Together, $\alpha_{i}$ and $\gamma_{i}$ allow for cross-sectional heterogeneity in both the level and age-profile of the deterministic component of earnings. The idiosyncratic stochastic component comprises two parts: $z_{\text {iat }}$ is a first-order autoregressive persistent shock and $u_{i a t}$ is a first-order moving-average transitory shock. We allow the variances of both shocks, $\sigma_{\varepsilon, a}^{2}$ and $\sigma_{\eta, a}^{2}$, to be quadratic functions of age, and the auto-regressive parameter, $\rho$, to be a cubic function of age. The movingaverage parameter, $\theta$, is assumed to be fixed across ages.

The model parameters are estimated separately for male and for female graduates using the BHPS sample described above. Estimation takes place in three stages:

1. Regress log earnings on the observed characteristics $X_{\text {iat }}$ and store the residuals as $\hat{y}_{i a t}$.

2. Calculate the sample auto-covariance function of the residuals $\hat{y}_{i a t}$ at each age for up to 10 lags. This generates a set of estimated auto-covariances, côv $\hat{y}_{a}, \hat{y}_{a-d}$ for $d=0, \ldots, 10$.

3. Choose the parameters of the earnings model to minimise the distance between the sample auto-covariance function and the theoretical autocovariance function implied by the model. Each element of the autocovariance function is weighted by $n_{a, d}^{0.5}$, where $n_{a, d}$ is the number of observations that were used in the construction of the sample autocovariance at age $a$ and lag $d$. In total, 374 moments were used in the estimation.

\section{Models for annual employment}

We define an individual to be non-employed in year $t$ if they are observed to have annual earnings less than $£ 1,000$ in that year. We estimate three models for employment dynamics: the probability of moving from employment to nonemployment, the probability of moving from non-employment to employment, and the annual earnings of re-employed workers. 


\section{Entry to employment}

The probability of a previously non-employed worker becoming employed is assumed to be a probit model with age and duration of non-employment as independent variables. Age enters as a quartic polynomial. Duration enters as dummy variables for one year, two years and more than two years.

\section{Exit to non-employment}

The probability of a currently employed worker becoming non-employed is assumed to be a probit model with age and log earnings as independent variables. Age enters as a quartic polynomial. Log earnings enter as a quadratic polynomial.

\section{Re-entry earnings}

Log earnings of a previously non-employed worker are assumed to be a function of age, duration non-employed and last log annual earnings before becoming nonemployed. Age enters as a quartic polynomial, duration enters as dummy variables for one year and more than one year, and last log annual earnings enter linearly.

\section{Simulating the BHPS model for earnings and employment}

The estimated earnings and employment models are simulated alongside each other, using the simulated earnings as inputs to determine the probability of becoming non-employed and the re-entry earnings upon re-employment. The only thing that remains to be specified is how the stochastic component of earnings upon re-employment is divided between the persistent and transitory components. This is done differently for males and females. For males, it is assumed that the transitory component is equal to the stochastic component of the re-entry earnings equation; the persistent component is equal to the remainder. For females, it is assumed that the persistent component is a weighted average of the persistent component as just described for males, and a random draw from the unconditional distribution of the persistent component (assuming full employment) at the relevant age; the weights used are 0.35 on the former and 0.65 on the latter. These specifications were chosen because they were found to generate employment patterns and re-entry earnings distributions that match the BHPS well at each age.

To generate a simulated series for raw earnings from the simulated series for logs, we first add back the estimated quartic age profile from the first-stage regression. Next we randomly assign each simulated individual to a region / ethnicity group, according to the observed region / ethnicity distribution. We then add back the relevant region / ethnicity constants. Finally, we add back the intercept term that corresponds to the year effect for the most recent year (2006) and exponentiate log earnings to obtain raw earnings.

\section{Adjusting for consistency with the LFS}

The final step is to adjust the cross-sectional distributions of non-zero earnings to be consistent with the observed cross-sectional distributions of non-zero earnings in the LFS. To do this, we calculate the following percentiles of the log-earnings distribution 
in the LFS at each age: 123451015202530354045505560657075808590 95 99. Each percentile is smoothed across ages using a five-point moving average. For each simulated log-earnings realisation, we calculate its rank in the simulated distribution at that age. We then re-assign it the corresponding log earnings from the smoothed percentiles in the LFS, using linear interpolation to evaluate ranks that lie between the percentiles listed above.

Two things should be noted. First, non-employed simulations (i.e. those with zero earnings) are not affected by this transformation; hence, the fraction of people employed at each age is left unchanged. Second, since annual earnings in the LFS are calculated as weekly earnings multiplied by 52 , it is likely that the LFS overstates earnings in the bottom parts of the distribution, due to the presence of part-year workers.

\section{Comparison with previous work}

In previous work, we used the cross-sectional earnings distributions from the LFS to estimate age-specific marginal distributions of earnings. We then modelled the twoyear dependence structure in earnings as a bivariate t-copula, which we estimated using the small two-year panel dimension of the LFS. One problem with this approach is that it forces earnings to be a first-order Markov process. This is inconsistent with a large literature on modelling earnings dynamics, which shows that there are important longer-run correlations in individual earnings. Importantly, our previous model abstracted from unobserved fixed effects, highly persistent shocks to earnings and also purely transitory earnings shocks.

Our new approach maintains the philosophy of using the larger cross-sectional LFS samples to estimate cross-sectional distributions and the smaller panel surveys to estimate dependence. However, we now allow the dynamic process to be characterised by fixed effects, persistent shocks and transitory shocks; this generates dynamic properties for earnings that better reflect the earnings fluctuations that workers experience over their careers. Since the model allows for non-parametric estimation of marginal earnings distributions, the resulting process for log earnings is not a linear Gaussian process (as in most of the literature). However, the dependence structure implicit in our simulations is consistent with a multidimensional Gaussian copula. In this limited sense, the model is more restrictive than our earlier one (which was based on a bivariate t-copula). However, the current model is far more general in that it relaxes the first-order Markov assumption. We view this as a big advantage over our previous work. 